\title{
PHILOSOPHICAL AESTHETICISM
}

\section{SEBASTIAN GARDNER}

THоugr neither art nor affect had any importance in the original programme of analytic philosophy, in the course of its development anglophone philosophy has incorporated both within its bounds: debates concerning the nature of aesthetic judgement, the representational, expressive, and other dimensions of works of art, the psychological role of emotion and its differentiation from other species of mental state, have become sophisticated and fine-grained. The approaches taken in analytic aesthetics and philosophy of mind remain, however, quite distinct from and largely at variance with the views of art and affect found in Continental European philosophy. There is, of course, no such thing as 'the' Continental view of art or of affect, and equally obviously, not all Continental philosophers concern themselves with either. Yet there is in philosophy after Kant a constant preoccupation with states of feeling and the meaning of art, and a marked tendency to claim for art and affect an extremely high philosophical importance, which goes well beyond the interest of early modern philosophy in passion and sentiment, and which has no analogue in analytic philosophy.

I am grateful to Brian Leiter for very helpful comments on an earlier draft of this essay, and to the Arts and Humanities Research Council and the Philosophy Department of University College London for research leave that enabled its completion. 
B. Leiter and M. Ros\$n Chap03.tex V1 - May 18, 2007 12:02 A.M. Page 70

A comprehensive survey of these developments would require a very great deal of space. What I aim to do here is to consider one strand in post-Kantian thinking about art and affect that is in my view especially important and distinctive. This is the view that art and affect are not merely central topics of philosophy, but must be included among the very grounds of philosophical thought. On the view to be examined, art and affect in certain of their forms are philosophically cognitive, and the task of philosophy is dependent, in some sense and at some level, upon their cognitive contribution. What this means more exactly will emerge in due course.

The historical origin of this outlook lies in early German Romanticism, and there is a loose sense in which all of its forms may be described as Romantic. It cannot, however, be identified with Romanticism tout court, because early German Romanticism incorporates specific metaphysical ideas which are rejected by later figures in the tradition that I am concerned with. Philosophical Aestheticism, as I will call the kind of outlook that I will be focusing on, is defined not by any specific philosophical doctrine but by the kind of strategy that it employs to establish the philosophically cognitive status of Aesthetic phenomena. ${ }^{1}$ Section 1 describes and analyses this strategy, and Sections 2 and 3 examine some of its most striking historical instances. Section 4 looks briefly at two important historical critiques of Philosophical Aestheticism. Finally in Section 5 I will say something about the reasons we may be thought to have for taking Philosophical Aestheticism seriously.

\section{The strategy of Philosophical AESTHETICISM}

1. If Aesthetic phenomena are to contribute to the task of philosophy, it is necessary that they should exhibit significant rationality. Whether ordinary, pre-philosophical consciousness supports this proposition is doubtful. Works

\footnotetext{
1 I will use 'Aesthetic phenomena' as shorthand for 'works of art and/or states of feeling held to incorporate philosophical cognition'. This usage of 'aesthetic' harks back to the broader meaning that the term carried, reflecting its Greek root, in early modern philosophical discourse up to and including Kant, as concerning matters of feeling in general. The qualification 'Philosophical' distinguishes the position I am concerned with from aestheticism in the nineteenth-century sense of l'art pour l'art, with which there is no logical connection (on the contrary: if art is its own end, then no cognitive end may be attributed to it). Philosophical Aestheticism is also distinct from Kierkegaard's concept of the aesthetic as an existential orientation.
} 


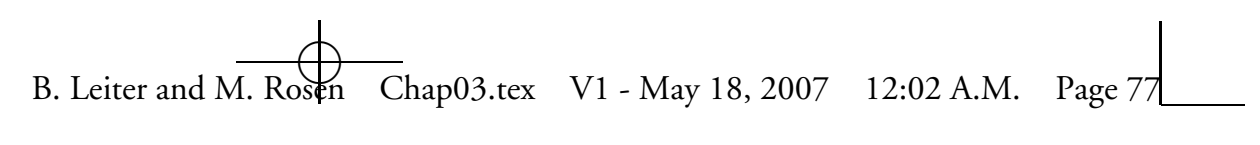

SEBASTIAN GARDNER

77

of art and states of affect may incorporate discursive, propositional elements, but what distinguishes them as instances of art and affect is something other than their discursive or propositional form, and moreover, something on account of which they are distanced from the states of belief and claims to knowledge which occupy philosophy's primary focus. Art and affect do not elude the net of rationalization altogether: some sort of rationality must be involved in responding to art and in states of full-fledged emotion, if not of mere feeling, since judgements of artistic worth are argued about and emotions are assessed for appropriateness. Perhaps, as some analytic philosophers have argued recently, art and affect assist cognition indirectly. But the fact remains that states of affect and works of art present themselves in the first instance, in contrast with other forms and objects of consciousness, as at least partially disconnected from reason, as distinct from cognition as ordinarily understood, and as standing only in a loose and indirect sense under the requirement of justification. Moreover, common-sense psychological lore affirms the assumption of seventeenth-century moral psychology that a deep problem is set by the susceptibility to passion at the root of human nature, the power of affect to pervert and override rational judgement. ${ }^{2}$

It does not follow that common sense endorses the strong, Platonic view that Aesthetic phenomena are necessarily and in all respects antagonists of reason - this requires additional metaphysical and epistemological assumptions. But it does give prima facie reason for doubting that art and affect have a proper place among the grounds of philosophical reflection. The most that can be claimed, it may be supposed, is that there is something right about the Romantic's endeavour to show that art and feeling have a proper place in human life, while the Aestheticist's attempt to give a more precise, philosophical form and meaning to this diffuse and nebulous idea must be rejected as ill-conceived.

If common sense fails to support, and to some extent resists, the idea that Aesthetic phenomena have inherent rationality, then two things are necessary. In the first place, the scope of the Aestheticist claim needs to be narrowed down: a distinction must be drawn between forms of affect that express practical, empirically derived motivation - what would traditionally be called passion - and those contemplative, disinterested forms of affect for which the Aestheticist claims philosophical significance. Second, because common sense does not provide Philosophical Aestheticism with a sufficient basis, an

\footnotetext{
2 See James, Passion and Action, $10 \mathrm{ff}$.
}

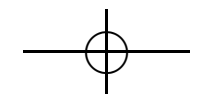




\section{B. Leiter and M. Ros $\oiint_{n}$ Chap03.tex V1 - May 18, 2007 12:02 A.M. Page 78}

injection of philosophical theory is required: the Aestheticist must argue that, when the right philosophical assumptions are in place, the features of art and affect which may seem to show their irrelevance to the task of philosophy are converted into features that make them unique candidates for discharging it. 2. The question arises next whether anything general can be said about which kind or kinds of philosophical theory are capable of playing the relevant role. Historically, the association of Philosophical Aestheticism with the post-Kantian, transcendental tradition is very strong, but it should be asked if it is strictly necessary, and more specifically, whether Philosophical Aestheticism can make sense in the context of philosophical naturalism. What makes the latter question especially pertinent is the consideration that three figures who have made major contributions to the formation of a naturalistic world-view_-namely Hume, Nietzsche, and Freud_regard affect (and, in Nietzsche's case, also art) as of outstanding philosophical importance.

It is no accident that naturalism in moral theory has frequently emphasized the role of affect, since states of feeling are obvious candidates for materials with which to construct naturalistic accounts of value. This means, in the first place, that the forms of affect most significant for naturalism are precisely those which Aestheticism puts to one side, the 'interested' ones which register the practical concerns of the empirical subject. More deeply, there is a crucial difference between the way in which affect figures for the naturalist and the way in which it does so for the Aestheticist. Naturalism explicates affective episodes, and aesthetic experiences, in terms of causal transactions between empirical objects and empirical subjects. The causality here, though it need not exclude relations of meaning, must be constrained in order for the analysis to qualify as interestingly naturalistic. ${ }^{3}$ Now as argued above, the meaning which can be ascribed to affect on the basis of our ordinary conceptions of emotion and feeling does not support Aestheticism, and while any interesting naturalism is certain to go beyond common sense, it hardly seems possible that any naturalism that is serious about its commitment to continuity with the results and methods of natural science will be motivated to extend common sense in the direction proposed by the Aestheticist - that is, to treat art and affect as media of philosophical cognition. Philosophical

\footnotetext{
3 Scheler, The Nature of Sympathy, p. xlix [Wesen und Formen der Sympathie, 14]: the 'higher' emotions, love and sympathy, 'can also be of significance, indeed crucial, interest to metaphysics ... but only if it can be assumed that their manifestations are ... incapable of further analysis in empirical or genetic terms'; they may then be considered 'functions of a special kind which bring us closer to the very foundation of all things'.
} 
B. Leiter and M. Rosłn Chap03.tex V1 - May 18, 2007 12:02 A.M. Page 79

naturalism has already what it considers an adequate conception of the proper tool of philosophical cognition, viz. appropriately confirmed empirical theory. This allows art and affect to figure for the naturalist as objects of philosophical investigation, to compose or provide access to the data from which empirical theories are extrapolated, and thus also to furnish materials for the construction of psychological theories (of morality etc.) for which philosophical significance may be claimed. But it does not allow them to compose an autonomous cognitive resource. Hume's essay on taste and his theory of the passions are not the last word in naturalist analysis of art and affect, but they give a good idea of its general character: philosophical naturalism understands art and affect in psychological terms, and naturalistic psychology does not support the ascription to art and affect of the kind of trans-psychological meaning claimed by Aestheticism. (Nietzsche's relation to Aestheticism, however, requires further discussion, and I will return to it later.)

3. In order for art and affect to be argued up into a position within the core of philosophy, philosophy must first of all find itself in the situation of being unable to do something that it needs to do. In order for this to come about, two opposing vectors are required: on the one hand, a conception of the task of philosophy that is relatively demanding, and on the other, a theory explaining why the demand cannot be met without Aestheticist supplementation. Conceptions of philosophy that do not bind it in advance to a definite goal which there is no guarantee of its being able to achieve-for example, the relatively modest conception of philosophy as merely an adjunct to the natural and human sciences, responding to their difficulties as and when they occur, or as merely one participant in the conversation of mankind-will not be capable of generating the cognitive deficiency or shortfall, the vacant portion of philosophical space, required for the Aestheticist strategy to be set in motion.

The Aestheticist must, therefore, make it plausible that the deficiency is a consequence of some limiting feature inherent in the very nature of philosophy. Candidates for this feature, Aestheticists have argued, include the purely discursive character of philosophy's medium, and its commitment to a particular, bounded conception of explanation. Also required from the Aestheticist is an account of why art and affect, as opposed to some other non-discursive phenomenon, should be regarded as the appropriate means to compensate for the deficiency of philosophy, a point to which I will return shortly. 


\section{B. Leiter and M. Ros $\oiint_{n}$ Chap03.tex V1 - May 18, 2007 12:02 A.M. Page 80}

4. There are several respects in which the attempt to argue for Philosophical Aestheticism risks miscarrying. Analysis of the logical dangers to which the view is exposed reveals much about what constitutes it and distinguishes it from neighbouring philosophical positions, whilst also showing that successful execution of the Aestheticist strategy — far from being a quick and easy route to philosophical solutions - is a delicate matter.

The fundamental problem lies in the seemingly paradoxical claim of Philosophical Aestheticism that art and affect harbour a content which is philosophical yet inaccessible to philosophy. There are two levels of paradox here. First: If the content is inaccessible to philosophy, then how can it be a philosophical content? Second, even if this first paradox can be dissolved, the Aestheticist's claim appears to confute itself: If the Philosophical Aestheticist can access the content in question, how then can it be described as inaccessible to philosophy? It would seem that, in order to describe the content, the Aestheticist must express it, to do which is to incorporate it into philosophy.

In light of these puzzles, it is natural to wonder if Philosophical Aestheticism is not a confused attempt to formulate a really much plainer and more plausible (but less exciting) idea, namely that reflection on art and affect, as on many other things outside pure philosophy, can lead to philosophical insight. If so, then Philosophical Aestheticism conflates the occasioning cause of a cognition with the cognition itself, and it misattributes to art and affect a cognitive achievement that belongs properly to philosophy.

The apparent logical difficulties of Philosophical Aestheticism recall the more familiar and general paradox which is often alleged to surround claims for the existence of the ineffable or inexpressible: Philosophical Aestheticism wishes to locate philosophical content over the horizon of philosophical discourse, just as the ineffable is purportedly located over the semantic horizon. This suggests, however, a way in which the charge of contradictoriness can be dealt with, for there is nothing self-stultifying in asserting the existence of ineffable knowledge, nor in talking about it from certain angles: we can talk about what results when we attempt to express the ineffable and even evaluate these results in some respect. What we specifically cannot do with the ineffable is actually express it. ${ }^{4}$ Similarly Philosophical Aestheticism can be restated so as to avoid incoherence. First, what makes the content ascribed by the Aestheticist to art and affect qualify as philosophical, is quite simply

\footnotetext{
${ }^{4}$ I follow Moore, Points of View, 155-6. Whether or not Moore's Wittgensteinian view that nonsense results from our attempts to express the ineffable, to say what can only be shown, would accommodate Philosophical Aestheticism, is a further matter.
} 
B. Leiter and M. Ros\$n Chap03.tex V1 - May 18, 2007 12:02 A.M. Page 81

the relation which it is revealed to have to philosophical needs once it has been taken up and deployed in philosophical reflection. Second, it does not follow from the Aestheticist's ascription of philosophical content to art and affect, that the ascription expresses the content in question. The relation is not so direct. What the Aestheticist does is identify the conditions under which the content is disclosed, without itself bringing it about that those conditions are realized: realization of the conditions for apprehension of the content is reserved for Aesthetic consciousness. The Aestheticist thus identifies a cognitive perspective in terms of how it is afforded, viz. Aesthetically, without actually expressing its contents. When the Aestheticist undertakes description of the content ascribed to art and affect, the relation between the two is like the relation between a poem and its paraphrase, or the relation between a proposition containing an indexical element thought in situ and the same proposition entertained unsituatedly, or the relation between a thought presented alongside its apodictic evidential basis and the same thought detached from it: the Aestheticist's claim is that the content is not truly thinkable, in its full significance, outside the Aesthetic context.

The appearance of paradox thus rests on an ambiguity between two different senses in which a content can be accessible (internal) to philosophy. The content ascribed to art and affect is inaccessible, external to philosophy, in the sense that it cannot be grasped without occupying the requisite Aesthetic state of mind or perspective, in a way that is not required for philosophical cognition in general; yet it is accessible, internal to philosophy, in the sense that the content is disclosed to a state of mind or perspective the conditions for which can be stated philosophically. Philosophical Aestheticism, in describing the content of art and affect, does therefore make a claim to philosophical cognition, but this claim is distinct from the cognition that it ascribes to art and affect: it is cognition, one level up, of the conditions under which the latter is available.

There is a further point worth making here. The Aestheticist conception of art and affect as perspectives brings out the contrast with philosophical naturalism, for which they are instead empirical objects: whereas the naturalist looks at art and affect, the Aestheticist seeks to see things by means of them, regarding art and affect as extensions of our subjectivity, which raise it to a higher power.

5. Supposing that Philosophical Aestheticism escapes paradox, a further, no less substantial problem presents itself. Even if the Aestheticist claim 


\section{B. Leiter and M. Ros\&n Chap03.tex V1 - May 18, 2007 12:02 A.M. Page 82}

is coherent, can it be justified? There is a clear danger of dogmatism or arbitrariness. The epistemological worry is best illustrated in historical terms.

The neo-classical orthodoxy which dominated aesthetic theory up until the late eighteenth century - until the dawn of Romanticism - allocated to art a determinate place within an already complete intellectual edifice. Art was conceived as the imitation of nature, where 'nature' meant neither sensible appearance nor extended matter but the essential, underlying structure of the world, conceived as divine creation. 'Nature' was therefore, as well as being a metaphysical principle realized in all actual existence, also a norm, an objective principle of (moral) rightness, and in many contexts the term was used interchangeably with 'reason'. The correlated objectivist, neo-classical view of beauty as apprehension of the moral-rational order of things allowed works of art to be conceived as possessing truth simply on account of their exhibiting beauty. To the extent that art had a philosophical role, as distinct from a moral-didactic function, it was that of merely confirming or giving illustrative form to a philosophical outlook that had been arrived at independently.

Neo-classical formulae appear to us now to impose on art metaphysical conceptions which are alien to it: neo-classical aesthetics fails, it seems to us, to give art its proper due, instead reducing art to philosophy's lookingglass. ${ }^{5}$ Philosophical Aestheticism must be able to meet the charge of similarly merely reading into art what it wishes to find there. It can do this by showing that the specific gap that it locates in discursive philosophical understanding is one which it is specifically appropriate for art and affect to fill-by revealing an affinity or congruence between the nature of art and affect and the philosophical content attributed to it. The Aestheticist must show therefore that distinguishing features of Aesthetic phenomena-their resistance to objectualization, their interstitial position on the borderline between sensation and thought, intuition, ${ }_{5}$ concept-suit them to the cognitive role ascribed to them. If the philasophical conceptions employed in the Aestheticist interpretation of art and affect are prompted by art and affect themselves - if there is an intelligible route from the Aesthetic to the philosophical conceptions employed in its interpretation - then Philosophical Aestheticism can rebut the charge of being arbitrary in the manner of neoclassicism: it can claim to have established an internal and reciprocal relation between philosophy on the one hand, and Aesthetic phenomena on the other.

\footnotetext{
5 On this theme, see Hilmer, 'Kunst als Spiegel der Philosophie'.
} 
B. Leiter and M. Ros\$n Chap03.tex V1 - May 18, 2007 12:02 A.M. Page 83

6. In view of the key role played by the appeal to privileged states of mind as conditions for the thinkability of the content ascribed to art and affect, Philosophical Aestheticism has something in common with mysticism. It is however important to locate Philosophical Aestheticism at the right point on the continuum of outlooks that may be brought under that heading. In the first place, Philosophical Aestheticism need not assert an independent non-discursive capacity for philosophical cognition that operates outside the context of philosophical reflection and that transcends altogether the cognitive capacities of ordinary, pre-philosophical consciousness: it may on the contrary argue for continuity between Aesthetic consciousness and discursive or ordinary consciousness. Two ways in which this can be done are the following. First, the relevant Aesthetic consciousness may be claimed to lie immanently in ordinary consciousness, contained in its deep background, Philosophical Aestheticism doing no more than to bring this implicit affective dimension to light. Second, insight into the philosophical content of art and affect may be held to depend upon a context of prior philosophical reflection. Thus in German Romantic speculation, the lacuna in philosophical understanding which Aesthetic insight is held to fill, is sometimes regarded as a 'presupposition' or 'postulate', that cannot be cognized determinately but which it can be shown to be necessary for us to think in an indeterminate form. The specific epistemological contribution of art and affect is then to give objective reality to the postulate, i.e. to show that it is not merely a postulate. On this account, art and affect are sub-adjacent to philosophical discourse: their contribution to philosophical cognition is not autonomous but depends upon, and can only occur within, a context of argument and reflection. ${ }^{6}$

It is clear from what has been said that the Aestheticist strategy cannot pretend to take the form of a strict proof. Making Aestheticism plausible involves a complex hermeneutical movement in which philosophical reason, dissatisfied with itself, looks outside to discover elements with the aid of which it can restore itself to equilibrium, and reaches a point where it recognizes that what it needs, but cannot generate from its own discursive resources, is presented in art and affect. $^{7}$

\footnotetext{
${ }^{6}$ See the distinctions in Henrich, Between Kant and Hegel, 70-1.

7 The connection of Philosophical Aestheticism with post-Kantian philosophy deserves brief comment. The relation is strictly contingent, in that nothing in the definition of Philosophical Aestheticism requires the philosophical knowledge claimed for the Aesthetic to be transcendental, and historically there have been theories, typically of a Neoplatonistic stamp, which reserve some portion of philosophical knowledge for states of higher feeling (Cambridge Platonism, Rousseau, Shaftesbury).
} 


\section{B. Leiter and M. Ros\&n Chap03.tex V1 - May 18, 2007 12:02 A.M. Page 84}

7. The history of post-Kantian attempts to interweave philosophy with art and affect encompasses, as noted earlier, a wide range of views. In order to be clear about which of these count as Aestheticist, two distinctions are important.

On the spectrum of different views of relation of art and affect to philosophy, Philosophical Aestheticism is flanked on each side by two other views, one weaker and one stronger. The weaker view, which may be called Aesthetic Parallelism, agrees that art and affect have cognitive import and are to be integrated with philosophy in a systematic fashion, but denies that there is any respect in which the Aesthetic should be accorded a cognitive facility which outstrips philosophy: it affirms only parallels between their respective contents. The extent of the parallel is left open: the Parallelist may hold either that Aesthetic cognition equals, or that it falls short of, philosophical cognition, but in either case the dependence, affirmed by the Aestheticist, of philosophy on Aesthetically grounded insight, is denied.

The stronger view, Aesthetic Subversivism, is an inversion of the Platonic view. Like Plato, it regards the relation of philosophy to art and affect as necessarily antagonistic, but it holds, against Plato, that the claims of philosophy are subverted, 'overthrown', by art and affect. Characteristically associated with Subversivism is the complaint that philosophy has sought, in the history of its theorizing about Aesthetic matters, to neutralize, disempower, or 'disenfranchise' art and affect. ${ }^{8}$ Subversivism thus contradicts the positive, harmonious, reciprocal relation of philosophy to art and affect affirmed by Philosophical Aestheticism.

The distinction of Subversivism from Aestheticism is reflected in the account that each gives of how the limitations of philosophy come to be recognized. In the Aestheticist case, the limitations of philosophy are already in place-they have already been discerned and comprehended by philosophy-before art and affect make their appearance. On the Subversivist view, the limitations of philosophy must be shown by art and affect themselves. Subversivism

What distinguishes post-Kantian Philosophical Aestheticism is simply its greater methodological selfconsciousness and theoretical intricacy, this being a direct consequence of its absorption of empiricist and Kantian lessons concerning the general epistemological difficulty attaching to metaphysical claims. Non-transcendental Philosophical Aestheticism belongs to a philosophical world in which the possibility of metaphysics and theology may be taken for granted and, though not for that reason lacking interest, belongs to a different story from that which this essay is concerned with.

${ }^{8}$ See Bernstein, The Fate of Art: 'Throughout its history philosophy attempted to tame art, to suppress its tendential protest to the reign of theory' (p. 12). Bernstein envisages art as the critique of philosophical cognition. 
B. Leiter and M. Rosłn Chap03.tex V1 - May 18, 2007 12:02 A.M. Page 85

thus imposes a considerably heavier burden on art and affect than does Philosophical Aestheticism.

This difference is associated with another. The consequences for philosophy that are held to follow according to Subversivism are typically of a fairly extreme character: Aesthetic Subversivism, especially in French neo-structuralist philosophy, is associated with the promotion of radical skepticism, relativism, perspectivism, or anti-realism. Philosophical Aestheticism by contrast asserts only a limited aporia in philosophical reason, and does not pronounce a negative verdict on its general competence. For this reason Aestheticism does not encounter the difficulty for Subversivism that will be described later.

\section{Early Aestheticist strategies: German Romanticism}

So far the characterization of Philosophical Aestheticism remains purely formal. In this section and the next, it will be seen in what ways the schema can be filled in.

That Philosophical Aestheticism should have emerged first in the postKantian period is, in view of what was said above, no accident. Kant's philosophy, under the interpretation and assessment which prevailed in the 1790s, furnished exactly the conditions described above. (1) Kant had argued conclusively, in the eyes of his most philosophically advanced readers, that there are a priori conditions on theoretical and practical cognition, the correct conception of which is found not in early modern rationalism but rather in Kant's transcendental theory of experience and metaphysics of morals. Also endorsed was (2) Kant's view that philosophy, as the expression of our highest cognitive ambition, is committed to attaining cognition of the (trans-empirical) unconditioned, and to achieving systematic form. This double demand would be met ideally by the foundation of philosophy on a single principle. Kant had not furnished this principle, but more immediately problematic was (3) Kant's restriction of claims to knowledge in the context of theoretical reason to the sphere of the (empirically) conditioned. Kant's claim that his Critical system, through its practical part, reconciled (2) and (3), was widely rejected-meaning that, if Kant's reasoning to (2) and (3) were correct, philosophy had shown itself to be incapable of meeting the demands that it rightly places on itself. 


\section{B. Leiter and M. Ros\&n Chap03.tex V1 - May 18, 2007 12:02 A.M. Page 8\&}

One response was provided by Fichte's Wissenschaftslehre, which offered the 'absolute I', the I that posits itself as absolute and the Not-I in opposition to itself, as a single principle that expresses the unconditioned and secures philosophical completeness. Early German Romanticism, inspired by Fichte's success in showing the potential for further development of Kantian thought, but dissatisfied with Fichte's claim to have located the required single principle, formulated itself at this point as an alternative. In this context there emerged over a short period of time an extraordinary number and variety of Aestheticist ideas.

1. Perception of Fichte's shortcomings, taken as symptomatic of the whole single-principle approach, was one element, to the fore in motivating early German Romantic Aestheticism, but in the background, and also of crucial importance, were the proto-Aestheticist ideas of F. H. Jacobi and Friedrich Schiller.

Shortly after the publication of the Critique of Pure Reason, but before its full effect had begun to be felt, Jacobi had succeeded in posing a radical questionmark over the ambition of systematic philosophy. Jacobi's Concerning the Doctrine of Spinoza (1785) belonged at one level to a local debate concerning the interpretation of Lessing's religious views, but its real message concerned an issue of maximal philosophical scope: the competence of human reason. ${ }^{9}$ According to Jacobi, the consistent application of the principles of reasoning and explanation to which philosophy is committed by its very (systematic, rationalistic, concept-bound) conception of its task, has only one possible outcome: a metaphysics that denies the existence of God, individual personality, and human freedom. Spinoza's great achievement, Jacobi insisted, had been to demonstrate incontrovertibly these nihilistic entailments of philosophical reason.

The only means of avoiding this catastrophic outcome, Jacobi argued, is to embrace a non-systematic, non-rationalistic philosophy that, under the name of Hume and with appeal to his authority, firmly and aggressively subordinates philosophical reason to 'feeling' or 'faith', Gefühl or Glaube, a state of immediate assent to the directly given real existence of its object. ${ }^{10}$ The broad sweep of Jacobian Glaube ranges from the objects of ordinary empirical knowledge to the supersensible being of God and our freedom. The ultimate ground of beliefs formed through Gefühl is, according to Jacobi, theistic: objects are given to us through what is in effect God's constant revelation. The

9 See Beiser, The Fate of Reason, ch. 2.

10 See Jacobi's summary account of what he means by Gefühl, in David Hume on Faith, Preface (1815), 563-4 [David Hume über den Glauben, Vorrede, 59-63]. 


\section{B. Leiter and M. Ros\$n Chap03.tex V1 - May 18, 2007 12:02 A.M. Page 8ไt}

dialogic character of cognition is, Jacobi holds, not excogitated by inference, but a further, internal component of the state of Glaube itself.

What Jacobi took to warrant this philosophical proposal, given his own admission of the logical unavoidability of 'Spinozism', was his claim to have shown, again through reflection on Spinoza, the incapacity of philosophy to ground its own basic principles: the possibility of knowledge of truth presupposes the unconditioned, but conceptuality is confined to the sphere of the conditioned. Connectedly Jacobi argued, with Kant and Fichte especially in mind, that the aconceptual, or trans-conceptual, character of all awareness of existence entails that the method of conceptual construction to which philosophical reason is confined leaves its results floating in logical space without existential validation. Thus, per Jacobi, we are forced to recognize the dependence of finite human reason on Gefühl, and while the adoption of Jacobi's point of view does require what he on one occasion calls a 'salto mortale', ${ }^{11}$ it is not an instance of credo quia absurdum. ${ }^{12}$

Though Jacobi raised the philosophical prestige of affect, his position did little for art; indeed, if genuine cognition, belief with existential import, depends on felt divine revelation, it is not clear that artistic creation will do more than reflect the cognitive impotence of human subjectivity working under its own steam independently of God. Schiller, by contrast, in his Letters on Aesthetic Education (1794-5), presented a powerful case for art's pre-eminence, centred on the claim that it provides the unique means of resolving the problem facing Kantian philosophical reason. Schiller's view of the problem has some points of contact with Jacobi's - they share a dissatisfaction with the one-sidedness of Aufklärung ideals-but a much finer focus, and while Jacobi deployed affect to the end of undermining philosophical systems like Kant's, Schiller advanced the claims of art with a view to preserving and perfecting a modified Kantianism.

Whereas Kant's third Critique had merely differentiated the sphere of the aesthetic and explained its independence from theoretical and practical reason, thereby establishing a place for art, but without showing art to be strictly necessary for the human telos, Schiller contended that we are compelled to create art in order to solve a problem which is set for us by our metaphysical natures, and which is otherwise unsolvable. ${ }^{13}$ The problem for Schiller is

11 Concerning the Doctrine of Spinoza (1785), 189 [Ueber die Lehre des Spinoza, 17].

12 For a short statement of Jacobi's position, see Concerning the Doctrine of Spinoza (1785), 230-4 [Ueber die Lehre des Spinoza, 162-72].

${ }_{13}$ On the argument of the Letters, see Beiser, Schiller as Philosopher, ch. 4. 


\section{B. Leiter and M. Ros $\oiint_{n}$ Chap03.tex V1 - May 18, 2007 12:02 A.M. Page 88}

based on Kant's familiar dualism: human subjects are constituted of two heterogeneous elements or principles - the form drive, related to Reason and Freedom, and the material or sensuous drive, related to Nature. Schiller maintains that it is impossible for the two to cohabit, and for either to fulfil the purpose which is intrinsic to it, without the introduction of some third, mediating element which will not simply connect but actually comprehend the two drives. No such problem is recognized by Kant: on his account, once Critical philosophy has established a degree of coherence in reason, whereby the various spheres of its employment are coordinated with one another, there remains only the practical problem of achieving victory for duty over inclination, i.e. the problem of becoming morally good (and thereby acceding to the highest good, in which the claims of morality and happiness are harmonized). This neglects, on Schiller's account, a deeper, underlying problem of the metaphysical wholeness of human being, the solution to which is provided by a third drive, the 'play drive', which disentangles, reconciles, and facilitates the mutual enhancement of the otherwise antagonistic form and material drives, which it in some sense subsumes. The play drive is precipitated or activated in us by the experience of beautiful art, in which Freedom and Nature are apprehended as one, and its hypothetical historical and political realization is what would allow humanity to raise itself to a condition of individual and collective wholeness. ${ }^{14}$

Jacobi's and Schiller's ideas, for all of their appeal to dissatisfied postKantians, also exhibit weaknesses. In the case of Jacobi, these are clear: the cost of according total epistemic authority to Gefühl is to give up on the hope of being able to reply to the skeptic, or the naturalist, with something more than intensity of feeling. It is also to surrender all of the philosophical gains made by Kant, in particular regarding the concept of autonomy.

\footnotetext{
14 That Schiller succeeds in showing that the problem of deeper wholeness arises within Kant's own terms (or even takes himself to do so) is doubtful: his argument is rather that these terms must be enlarged. What Schiller shows convincingly is that the need for a higher degree of wholeness than Kant allows for is indicated in the light of (i) common-sense intuitions about human goodness (as located in the person as a whole, not merely in her capacity for practical judgement), (ii) historical and political knowledge (concerning the atomism and mechanization of modern social life and its correlative distortion of human personality, and the miscarriage of political reason evidenced in France's postrevolutionary Terror), and (iii) Kant's own conception of our reason as striving to absolute unity. Schiller believes also that aesthetic experience wakens us to this need. What then follows in terms of Schiller's argument with Kant, as I consider next, depends on whether orthodox Kantianism can meet the challenge set, and whether Schiller can complete the further (and philosophically harder) task of showing the real possibility of the wholeness he says we are in need of.
} 
B. Leiter and M. Rosłn Chap03.tex V1 - May 18, 2007 12:02 A.M. Page 89

The weakness of Schiller's account is less obvious but more revealing of the specific direction pursued in German Romanticism. It lies essentially in Schiller's contradictory attempt to develop an Aestheticist position on foundations that stick closely to the letter of Kantian doctrine. The Aestheticist element in Schiller's theory consists in his claim that the Idea of a unity of freedom and nature is first given to us through Aesthetic experience and cannot be established through philosophical means in a form that makes it of real significance to us. The problem is that Schiller gives insufficient reason for thinking that this unity is not merely alluring, but also a rational possibility for us. Might not the Aesthetic unity of freedom and nature be a mirage, and its pursuit destructive? Kant will object that to grant nature a legitimacy equal to that of reason is simply to undermine morality. Schiller has something of an answer, in so far as he, first, attempts to show the inescapability of our need to achieve wholeness, to realize what he calls our infinite nature, ${ }^{15}$ and second, sketches a transcendental argument designed to show that the third thing, beauty and the play-drive, is implied as a possibility if not an actuality by the conjunction of thought and feeling that we actually find within us. ${ }^{16}$ Whether or not these parts of Schiller's theory (which make rather tendentious appeal to Fichte) are found convincing, there is a clear limit to what is achieved. The characterization of art in Schiller remains, so to speak, functional rather than cognitive: art projects an Idea of the unity of freedom and nature, and points us in its direction, such that, if we realize the Idea, then art will be describable as containing truth, in the weak sense of its having facilitated our realization of the Idea that it projects. But art does not give, in Kant's language, 'objective reality' to the Idea: Schiller does not show that the Idea of a higher unity possesses truth in a sense sufficient to warrant belief in its realizability.

Reflection on the imperfect Philosophical Aestheticism of Jacobi and Schiller yields the following formula, which governs German Romanticism: Aesthetic media can be claimed to yield access to the unconditioned, to the real existence of discursively inaccessible objects, and to the higher synthetic unity that is the proper telos of human development, but this claim must be, contra Jacobi, integrated with, rather than opposed to, systematic philosophy; in addition, the systematic philosophy in question must be one that departs further than

\footnotetext{
15 Given in Letter 11, pp. 73-7 [Briefe, 341-4] in terms of a bifurcation in man's nature between his 'Personhood' and his 'Condition', with some anticipation in Letter 9, pp. 55-61 [Briefe, 332-6]; see also Letter 14, p. 95 [Briefe, 352-3].

${ }^{16}$ Letters 18-22, pp. 123-59 [Briefe, 365-83].
} 


\section{B. Leiter and M. Ros\&n Chap03.tex V1 - May 18, 2007 12:02 A.M. Page 90}

Schiller from the letter of Kantian doctrine-just as, the German Romantics appreciated, Fichte's Wissenschaftslehre had done.

2. The philosophical beginnings of German Romantic Aestheticism lie in early, unpublished reflections of Hölderlin and Novalis. A fragment of Hölderlin's, 'Judgement and Being', makes a deep and original criticism of Fichte, to the effect that the I by its very nature cannot be absolute and so is not fit to play the systemic role assigned to it by Fichte. Hölderlin's argument is, in rough summary: (1) In judgement, a separation is presupposed: a judgement can only be a joining together, an identity of things that are originally articulated as distinct, namely its subject- and predicate-terms. (2) This applies also to the self-relation, the self-consciousness exhibited in the pure 'I' which judges, 'I = I', 'I am self-identical'. It follows that (3) the pure 'I' is inhabited by a separation. (4) The proper criterion for absolute being, 'absolutes Seyn', is the Spinozistic one of essential oneness, a degree of unity that precludes the possibility of separation (immanent separability being a mark of conditionedness and hence non-absoluteness). It follows (5) that the 'I' is ruled out as a candidate for absolute being. Fichte has, therefore, in making the 'I' absolute, confused Being with identity. Thus, while the absolute - that unitary, unconditioned being which, playing the logical role of Spinoza's one substance, stands as the real ground of the epistemological, explanatory, conceptual, and ontological orders ${ }^{17}$ — of course exists, it cannot be expressed in the form of a proposition about the I, nor about anything else: no proposition can express the absolute. A parallel line of thought appears in Novalis, who maintains contra Fichte that there must be a relation to an independent Not-I in order for the I to posit itself, and that when the I first posits itself, it does so within a 'sphere that encompasses' both I and Not-I and that therefore cannot be posited by the $\mathrm{I}^{18}$

Such critique does not leave Fichte without room for manoeuvre, but it opens the door immediately to new possibilities. So long as the aspiration to grasp the absolute is not abandoned-and it remains axiomatic for the German Romantics that all philosophizing must 'end in an absolute ground'19

\footnotetext{
17 The concept of the absolute was for the post-Kantian idealists not merely the name of a blank functional role within philosophical discourse: it could be known, so they argued, to have certain determinations, including infinite rationality and activity. These can be set aside, however, in the present context.

18 Fichte Studies, no. 8, p. 7 [Fichte-Studien, 107-8]. For discussion of Hölderlin's and Novalis's critiques of Fichte, see Frank, The Philosophical Foundations of Early German Romanticism.

19 Fichte Studies, no. 566, p. 167 [Fichte-Studien, 269].
} 


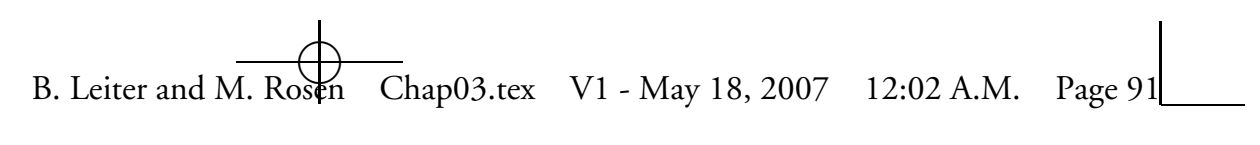

or at any rate direct itself towards doing so-what is suggested is that our relation to the absolute must be construed in some new way, one that will count as relatively indirect from the standpoint of discursive reason. If the Fichtean absolute I is not philosophically the end of the story, then we must conceive of there existing some hinterland to Fichte's landscape: we must suppose that, at the point where the self relates to itself by positing itself, it does so against a background that contains some more basic, pre-individual ground. 'Judgement and Being' gives no hint as to what should be said about the connection, which of course must exist, between the self and absolute being, but the whole of Hölderlin's later theoretical and artistic development is in a sense guided by the task of binding them together. For both Hölderlin and Novalis, the primacy of being over consciousness can be grasped, as in Plato's allegory of the cave, on the model of a light in which consciousness beholds itself, flowing from a ground which consciousness cannot bend back to illuminate. The being that grounds consciousness, that reflection cannot represent, may however be presented through Aesthetic means:

Philosophy is originally a feeling. The philosophical sciences conceptualize the intuitions of this feeling... Thus philosophy always needs something given-it is form ... Philosophy does not admit of construction. The borders of feeling are the borders of philosophy. Feeling cannot feel itself. ${ }^{20}$

The feeling Novalis speaks of is a feeling of the sphere that encompasses I and Not-I, of what Hölderlin calls absolute being. ${ }^{21}$ From the premise that reflection is conditioned and bounded by feeling (all that philosophical reflection can do is give form to the material supplied by feeling), Novalis reaches the double conclusion that philosophy cannot be a pure, free reflective construction in the way that Fichte envisages his Wissenschaftslehre as being, and that (because feeling 'cannot feel itself') philosophy cannot complete its aim of closing the circle on itself. ${ }^{22}$ Recognition that the aim of producing a complete, self-justifying philosophical system is strictly unfulfillable does not, however, mark the end of philosophical speculation. On the contrary, in the view of Novalis, and of his close philosophical associate Friedrich Schlegel, it provides it with a spur: philosophy will henceforth understand its task as one of infinite

\footnotetext{
${ }^{20}$ Fichte Studies, no. 15, p. 13 [Fichte-Studien, 113-14].

21 Or 'Seyn, im einzigen Sinne des Worts', which is available to us only in Aesthetic form, as beauty: see Hyperion (Die vorletzte Fassung), Vorrede, 236-7.

${ }^{22}$ Novalis has a complex theory of why it should appear otherwise-of why reflection should appear to itself autonomous - in terms of an illusion of inverted order: see Fichte Studies, nos. 15-17, pp. 12-14 [Fichte-Studien, 111-15].
}

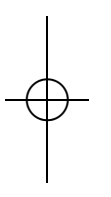




\section{B. Leiter and M. Ros\$n Chap03.tex V1- May 18, 2007 12:02 A.M. Page 92}

striving towards the systematic ideal and will stand alongside art's presentation of the discursively unpresentable, contributing to a comprehensive Aesthetic reinterpretation, or 'romanticization', of self and world. As Schlegel defines the new programme: 'Where philosophy stops, poetry has to begin' ${ }^{23}$ — 'Whatever can be done while philosophy and poetry are separated, has been done and is achieved. So the time has come to unite the two.'24

3. The German Romantic integration of Aesthetic media into philosophical speculation has further rationales, in addition to the post-Fichtean motive of resolving the aporia in the Wissenschaftslehre and penetrating to the true ground of the I. One is the metaphysical organicism of the Romantics: the idea that the world as a whole and all of its elements have organic structure, which allows it to be held that works of art, on account of the way that the special interpenetration of parts and whole which they exhibit raises them to a higher unity, exhibit in microcosmic form, and thus furnish cognition of, the true shape of reality. ${ }^{25}$

Another, of fundamental importance on account of its methodological character and independence from any specific metaphysical doctrine, for which reason it recurs again and again in post-Kantian philosophy of art, is the theory of the identity of the transcendental with the Aesthetic point of view. The concept of the transcendental, which Kant had employed in a relatively narrow epistemological way, becomes greatly expanded in German Romantic usage. ${ }^{26}$ Again the departure from Kant is grounded in a perceived deficiency of his system, this time in his alleged failure to explain how ascent can be made from the ordinary, pre-transcendental standpoint to the level of transcendental reflection. Here again the discursive shortfall meets with the German Romantic suggestion of Aesthetic compensation. The idea was first articulated by Fichte:

Perhaps one cannot express what fine art does in any better way than by saying that it makes the transcendental point of view the ordinary point of view.- The philosopher elevates himself and others to this point of view by means of work and in accordance with a rule. The beautiful spirit [der schöne Geist] occupied this viewpoint without thinking of it in any determinate manner; he is acquainted with no other viewpoint. He elevates those who open themselves to his influence to this same viewpoint, and he does that just as unnoticeably, so that they are not even aware of the transition.

23 Schlegel, 'Ideas', no. 48, p. 98 ['Ideen', 261].

24 Schlegel, 'Ideas', no. 108, p. 104 ['Ideen', 267].

25 Beiser explores this theme in detail in The Romantic Imperative.

26 'Transcendental is what is, should be, and can be, elevated', Schlegel, 'Athenaeum Fragments', no. 388, p. 79 ['Athenäums-Fragmente', 237]. 


\section{B. Leiter and M. Ros $\oiint_{n}$ Chap03.tex V1 - May 18, 2007 12:02 A.M. Page 93}

Let me make myself clearer: from the transcendental point of view, the world is something that is made; from the ordinary point of view, it is something that is given; from the aesthetic point of view, the world is given, but only under the aspect of how it was made. ${ }^{27}$

Fichte, as the quotation shows, envisages Aesthetic ascent to the transcendental as strictly inessential, since there is a 'rule' that the Fichtean philosopher can employ to elevate himself. Novalis and Schlegel by contrast treat the primary and central form of the transcendental viewpoint as intuitional rather than conceptual: on their view, Aesthetic media are what allow us to attain the transcendental, to enact in self-consciousness the shift from pre-Copernican to transcendental philosophy, and what provides assurance of the (peculiar) reality of the transcendental standpoint.

Just as Fichte's transcendental philosophy is anchored in moral freedom, and Schiller's philosophical writings have a moral-political purpose, so in German Romantic theory the significance of the Aesthetically induced transcendental standpoint is not exclusively or even primarily theoretical. The aporia in Fichte's philosophy, Hölderlin supposed, not only pertains to theoretical reason but amounts also to a practical or existential problem, which gives human life its basic form: because self-identity falls short of absolute being - because the self is essentially a unity, yet at the same time divided all the way down - self-consciousness as such is a problem for itself. Self-cognition of a theoretical and discursive sort does not allow the self to harmonize with itself, because it is premised on the distinction of subject and object, rendering it incapable of unifying the self's unity and multiplicity. A self-relation that achieves this unification is possible, however, in activity that has the form of poetic creation, in which the I steps outside itself. ${ }^{28}$ The same pattern, of according privileged practical and axiological significance to the Aesthetic, is repeated in Novalis' visionary, transfigurative 'magical idealism', ${ }^{29}$ and

\footnotetext{
27 Fichte, The System of Ethics, $\$ 31$, p. 334 [System der Sittenlehre, 353-4]. The same idea is employed in Schopenhauer, The World as Will and Representation, vol. i. 173, $\$ 34$, pp. 178-81, and $\$ 38$, pp. 195-200 [Die Welt als Wille und Vorstellung, i. 204, 209-13, and 230-6]. Fichte and Schopenhauer count, in terms of the distinctions made earlier, as Aesthetic Parallelists. For an original contemporary Parallelist account of the transcendental significance of art, see Sacks, Objectivity and Insight, $320-1$.

${ }^{28}$ Hölderlin calls this the formation of a 'pure poetic I'; see 'Operations of Poetic Spirit', 72 and 72-3n. ['Über die Verfahrungsweise des poëtischen Geistes', 252-5]. Hölderlin's idea that the dynamic of human life can be grasped adequately only in Aesthetic form is pursued by Henrich in Kunst und Leben.

${ }_{29}$ On which, see Beiser, German Idealism, pt. III, ch. 3.
} 


\section{B. Leiter and M. Ros\$n Chap03.tex V1- May 18, 2007 12:02 A.M. Page 94}

in Schleiermacher's Romantic account of religion as proceeding from an intuition or feeling of the infinite. ${ }^{30}$

4. While Hölderlin and Novalis argue for a radical Aestheticist turn within philosophy, a more philosophically conservative form of Philosophical Aestheticism, which agrees on the limitations of Fichtean philosophy but holds complete systematicity to be still attainable, was developed by Schelling in Part Six of his System of Transcendental Idealism. If Schiller's ideal of a unity of freedom and nature overshoots what the Kantian system warrants, it at least makes it possible to ask what revision of Kantianism would be sufficient to support Schiller's ideal, and to attempt to innovate Kantian metaphysics accordingly. This in effect is what Schelling does, in what is perhaps the finest integration of the claims of philosophy and of art in modern philosophy. In place of annexing a strong Aesthetic claim to a philosophical structure that has been designed to show the self-sufficiency of discursive reason, Schelling designs a post-Kantian system in which epistemological and metaphysical needs find their consummation in Aesthetic consciousness.

The task that Schelling sets himself in the System of Transcendental Idealism is to put together Fichte's transcendental idealism, in a somewhat reworked form, with a philosophy of nature that, though remote from and opposed to any materialistic naturalism, regards nature in a realistic light and not as a mere counter-posit to the self-positing I. The result is a philosophical system with a remarkable, two-in-one structure. The key to the coherence of Schelling's double system lies in his innovation of the model that he took to be provided by Spinoza: just as Spinoza's One Substance is represented in terms of the two attributes of thought and extension, so we can, Schelling suggests, conceive a single philosophical system as composed from two sides, that of the subject and that of the object. The subjective side yields a Fichtean philosophy of freedom, the objective a philosophy of nature. As Schelling develops the two system-sides, they are discovered to interlock, each leading round to the starting-point of the other. The question arises nonetheless, what establishes the unity of the system as a whole-what shows the worlds of each system to be one and the same, the subjective and objective to be identical. Philosophy cannot supply a principle to perform this role: the highest principles that it can articulate are the self's freedom and nature's productivity, which constitute and so cannot overcome the subject-object division. Philosophy

\footnotetext{
${ }^{30}$ See On Religion, esp. the Second Speech. Later this becomes a feeling of 'absolute dependence'; see The Christian Faith, Introduction, \$4, pp. 12-18 [Der christliche Glaube, xiii/1. 32-40].
} 


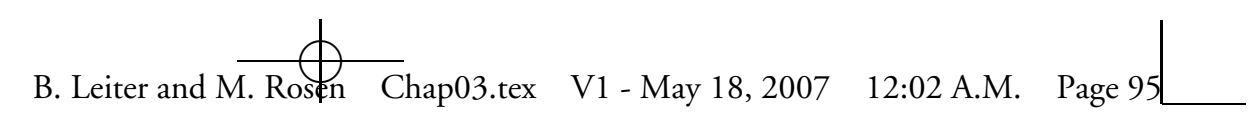

can do no more than postulate subject-object identity. This limit of discursive philosophy creates the context for Schelling's Aestheticism. The work of art, on Schelling's Romantic analysis, is an indissoluble unity of conscious and unconscious productive factors, of self and nature, freedom and necessity-a unity which, crucially, exists as such for the subject. Aesthetic intuition is thus what expresses subject-object identity and sets the seal of unity on Schelling's system.

Schelling's philosophy of art brings out well the way in which Aestheticism can avoid the paradox discussed earlier, by locating the Aesthetic's philosophically cognitive content in one sense inside and in another outside philosophy: the concept of the work of art, as Schelling analyses it, belongs to philosophical discourse, but what makes the concept more than an arbitrary discursive construction, and warrants the claim for its cognitive value, consists in an extra-conceptual, Aesthetic phenomenon. This is why Schelling describes the work of art as 'the only true and eternal organ and document of philosophy. ${ }^{31}$

5. Though outside the orbit of German Romanticism, a brief comment is due on Nietzsche, whose relation to Philosophical Aestheticism is characteristically complex. Nietzsche's account of art and affect, although it includes many naturalistic elements, is not confined to the Humean schema described in Section 1. Though opposed to the post-Kantian idealist tradition, Nietzsche carries forward the Romantic theme of the involvement of art with fundamental questions of value, and The Birth of Tragedy presents what appears to be a hyper-Romantic case for regarding tragic art as a condition of possibility for genuine value. Nietzsche did not hold long to the view articulated in this early work, and in his later writings he rejects Romanticism in no uncertain terms, keenly aware of art's potential to serve the ascetic ideal. ${ }^{32}$ And yet, even in the writings of his maturity Nietzsche supposes that Aesthetic notions hold their place within a post-metaphysical world-view, and indeed (in a way that is not typical of philosophical naturalists) that they are necessary if we are to orientate ourselves and flourish under modern conditions. In view of his generally skeptical stance, Nietzsche cannot be said to endorse squarely the Aestheticist claim that art is cognitive, and is better interpreted as upholding a non-cognitive analogue of Philosophical Aestheticism, in which art plays the trick of releasing us from the authority of a theoretical reason which has

31 System of Transcendental Idealism (1800), 231 [System des transcendentalen Idealismus, 627].

32 The Gay Science, bk. 5, sect. 370, pp. 327-31 [Die fröhliche Wissenschaft, 301-4]. 
become incompatible with life. ${ }^{33}$ Whether or not his position qualifies as Aesthetic Subversivism, as French neo-structuralist writing assumes, depends on how exactly the mechanism of release is understood and on more general issues in Nietzsche interpretation.

\section{Aestheticist STRATEgies in TWENTIETH - CENT URY PHILOSOPHY}

It may be asked how much, if anything, of Philosophical Aestheticism can survive the historical move away from classical German philosophy. That this is indeed possible is shown by Merleau-Ponty, Heidegger, and Adorno, all of whom take up Aestheticist positions. What they share, and what distinguishes them from the thinkers discussed in the previous section, is an intention to challenge, criticize, or revise ordinary, pre-philosophical selfunderstanding. So there is a shift in the goal of, and a new use for, the Aestheticist strategy: whereas Kant's early successors were seeking not to alter ordinary understanding but to embed it within systematic philosophy, and conscripted the Aesthetic to that end, the revisionary intentions of MerleauPonty, Heidegger, and Adorno mean that the Aesthetic is now set in opposition to ordinary self-understanding and to modes of philosophical thought that reflect and endorse what they consider its deficiencies. ${ }^{34}$

1. The philosophical positions which developed in the immediate postKantian context continue to conceive philosophy as, broadly speaking, a task of explanation, of uncovering the grounds of how things are and must be. Merleau-Ponty explicitly conceives philosophy instead as providing a special kind of non-explanatory description, which he calls 'giving voice to the

\footnotetext{
33 The trans-cognitive or para-cognitive character of Nietzsche's view of what art achieves goes back to his famous, cryptic remark in The Birth of Tragedy that it is 'only as an aesthetic phenomenon that existence and the world are eternally justified' (sect. 5, p. 52) [Die Geburt der Tragödie, 43].

${ }^{34}$ Whether this different style of employment of Philosophical Aestheticism counts as progress depends, of course, on matters of general philosophical outlook; what deserves emphasis here is simply that Philosophical Aestheticism itself is able to stand both independently of the strong systematic ambition of classical German philosophy and as a resource for those who affirm that ambition. Thus, if one considers that twentieth-century transcendental philosophy ultimately leads back to, rather than leaving behind, the concerns that motivated classical German philosophy, and if one also does not accept Hegel's execution of the systematic project (discussed below), then by no means may the forms of Philosophical Aestheticism discussed in the previous section be regarded as surpassed.
} 


\section{B. Leiter and M. Ros\$n Chap03.tex V1- May 18, 2007 12:02 A.M. Page 9}

experience of the world': 'phenomenological or existential philosophy assigns itself the task, not of explaining the world ... but rather of formulating an experience of the world, a contact with the world which precedes all thought about the world. ${ }^{35}$ This shift to a revelatory or expressive conception of philosophical cognition suggests immediately a convergence if not identity of aim with art, and a correlative conception of art as philosophically cognitive.

Merleau-Ponty's Phenomenology of Perception attempts to establish the existence of what Merleau-Ponty calls 'pre-objective' (also 'lived', 'unreflected') consciousness. At the pre-objective level there is, Merleau-Ponty claims, no distinction of subject and object: when the accretions of 'objective thought' are stripped away, we discover in perception an original point of connection between ourselves and the world that is completely unanalysable. Phenomenology can make us aware of this point and show that it is always presupposed in conceptual activity, but no philosophy can reach back by means of concepts to anything more primordial that might elucidate it. What is primarily revealed about the world from the pre-objective standpoint, according to Merleau-Ponty, is its indeterminacy: the world as perceived pre-objectively is not composed of distinct objects to which determinate characteristics can be assigned. The pre-objective is strictly ineffable, and because this is so, we cannot say how the objective, reflective conception of the world - to which Merleau-Ponty accords, of course, its own, relative validity - arises out of it, although we can know that it does so.

The path employed in the Phenomenology to establish these results consists in a critique of philosophical and psychological theories of perception, indicating their incoherences, explanatory failures, remoteness from phenomenological reality, antinomial structure, and so on. That this wholly negative procedure can never amount to proof of the reality of the pre-objective is a point acknowledged, indeed emphasized, by Merleau-Ponty. Art, however, in at least some of its forms, performs the same labour as the Phenomenology, employing positive and non-conceptual means. The artist whose expression of the passage from pre-objectivity to objectivity Merleau-Ponty regards as exemplary is Cézanne:

Cézanne did not think he had to choose between feeling and thought, between order and chaos. He did not want to separate the stable things which we see and the shifting way in which they appear [as do the Impressionists]; he wanted to depict matter as it takes on form, the birth of order through spontaneous organisation. He makes a basic

35 'Metaphysics and the Novel', 27-8 ['Le roman et la métaphysique', 54-5]. 


\section{B. Leiter and M. Ros\&n Chap03.tex V1 - May 18, 2007 12:02 A.M. Page 98}

distinction not between 'the senses' and 'the understanding' [a distinction of objective thought] but rather between the spontaneous organisation of the things we perceive and the human organisation of ideas and sciences. We see things; we agree about them; we are anchored in them; and it is with 'nature' as our base that we construct our sciences. Cézanne wanted to paint this primordial world... He wished, as he said, to confront the sciences with the nature 'from which they came'... By remaining faithful to the phenomena in his investigations of perspective, Cézanne discovered what recent [Gestalt, phenomenological] psychologists have come to formulate: the lived perspective, that which we actually perceive, is not a geometric or photographic one... it is Cézanne's genius that when the over-all composition of the picture is seen globally... [we have] the impression of an emerging order, of an object in the act of appearing, organising itself before our eyes. ${ }^{36}$

The identification proposed by Fichte of the aesthetic standpoint with the transcendental is here clearly reaffirmed: in Cézanne we find, as Fichte put it, the world given under the aspect of how it is made.

2. The idea that the work of art is concerned with a transcendental process of world-constitution belongs also to Heidegger, though Heidegger arrives at it quite differently, and carries it a step further.

It is best to start with the sections of Being and Time in which Heidegger lays out the category of 'mood', Stimmung. ${ }^{37}$ What is under consideration here is our affectivity, philosophical understanding of which has, he says, 'been able to make scarcely one forward step worthy of mention since Aristotle'. ${ }^{38}$ This situation is not peculiar to affect, but a result of the general limitations of philosophical understanding since the Presocratics, which Being and Time diagnoses as consisting in the error of according priority to the mode of being of presence-at-hand (Vorhandensein), and which Heidegger's exposition of our properly fundamental mode of being-in-the-world aims to overcome.

Despite the obvious enormous differences from Kant, there is a good sense in which the Heidegger's enquiry into Dasein is transcendental: Heidegger aims to explicate how there comes to be a world for us in terms that refer to the necessary, non-empirical structures that compose us, the subjects for whom the world is. The differences from Kant, stated baldly, are these: Heidegger expressly refuses to allow transcendental reflection to fix in advance our understanding of 'object' and 'condition of possibility' in a way that would narrow the field of inquiry to what Kant calls Erfahrung, objective

\footnotetext{
36 'Cézanne's Doubt', 13-14 ['Le doute de Cézanne', 24-7].

37 Being and Time, \$\$29-30, pp. 172-82 [Sein und Zeit, 178-89], and \$68 (b), pp. 389-96 [Sein und Zeit, 449-57].

38 Being and Time, 178 [Sein und Zeit, 185].
} 


\section{B. Leiter and M. Ros $\oiint_{n}$ Chap03.tex V1 - May 18, 2007 12:02 A.M. Page 99}

knowledge. Also and connectedly, Heidegger's transcendental inquiry aims to do something which Kant's does not do, namely to put in question, renew, and alter our grasp of the given. What causes Heidegger's transcendental analysis to reshape the field whose conditions of possibility it investigates is the fact that his primary interest lies, not in the constitution of human subjectivity, but in 'fundamental ontology': the question of Being which originally gives reason to make Dasein a theme of enquiry is a non-Kantian, supra-transcendental question, one which, if Heidegger is correct, neither ordinary, pre-philosophical consciousness nor philosophy hitherto has the resources to answer. This is why the transcendental enquiry into Dasein which sub-serves ontological inquiry into Being is bound to do more than revalidate the conceptions of ordinary consciousness: Heidegger needs to wring from ordinary consciousness, by means of transcendental analysis, an answer to a question which it does not even recognize.

Heidegger produces, accordingly, an account of affect which revises common-sense psychology. On Heidegger's view, the field of phenomena taxonomized by common-sense psychology under the headings 'belief', 'desire', 'feeling', etc., cannot be accounted for without going back to more basic dimensions of Dasein. Dasein's 'being-there' comprises, Heidegger proposes, two basic structures: 'state-of-mind' (Befindlichkeit, Dasein's finding-itself-tobe some way or another) and 'understanding'. Mood is that which expresses Befindlichkeit in ordinary consciousness (in Heidegger's language: mood is the ontic phenomenon that expresses the ontological existentiale of Befindlichkeit). Heidegger's revisions to the understanding of affect in common-sense psychology and its philosophical counterparts are several. (i) Mood carries a meaning which affective episodes, bound to particular entities in the world, cannot carry, but which they presuppose: mood registers (without representing) the ontological dimension of Dasein. In mood Dasein is 'brought before its being as "there" ', its own 'burdensome character', the fact that it is 'delivered over to the Being which, in existing, it has to be', the 'thrownness' (Geworfenheit) or 'facticity of its being delivered over'. ${ }^{39}$ Incorporated in this registering is a practical element: we turn 'towards or turn away' from that which mood discloses. ${ }^{40}$ Mood is thus cognitive, though again, not in the manner of Kantian experience: in contradistinction to empirical cognition, mood is cognitive by virtue of its 'saying' something to us without offering us any object to grasp or proposition to entertain; it instead takes in all of the

\footnotetext{
39 Being and Time, 173-4 [Sein und Zeit, 179-80]. $\quad{ }^{40}$ Being and Time, 174 [Sein und Zeit, 180].
} 


\section{B. Leiter and M. Rosen Chap03.tex V1-May 18, 2007 12:02 A.M. Page 100}

world. (ii) Mood is necessary: Dasein cannot be 'free of' mood, even though its mood may be 'bare' and invisible to introspection. (iii) Since the registering of Dasein's facticity is sufficient for the phenomenon of mood, mood presupposes no beliefs or desires; these representational states arrive later in the day. Indeed, mood is required for cognition, since cognition presupposes the existentiale of 'understanding', and understanding 'always has its mood'. ${ }^{41}$ (iv) Far from being logically secondary to emotion - a case of peculiarly vague emotion, or of emotion that has somehow lost track of its object-mood is the original, autonomous form of affect, which precedes and makes possible the affective episodes ascribed in common-sense psychology. It follows that affect in general has nothing to do originally or essentially with sensation, sensory affection, or corporeal conditions. Finally, (v) mood is a condition for practical orientation: it is what first discloses Dasein's being-in-the-world 'as a whole' and thereby 'makes it possible first of all to direct oneself towards something. ${ }^{42}$

In arguing for this interpretation of mood as a transcendental condition (more accurately, as the ontic manifestation thereof) Heidegger appeals to those of its characteristic features which define it for (though without, he holds, allowing it to be rendered intelligible by) common-sense psychology: the way we slip from one mood to another, the way moods give themselves as independent of any 'why or wherefore', their fitful proneness to decay and to improve spontaneously, their enigmatic and inexorable quality, and so on. Heidegger's later intense preoccupation with art-in 'The origin of the work of art', with its famous accounts of van Gogh and of Greek temple architecture, and in the attention Heidegger gives to poetry, especially that of Hölderlin, from the late 1930s onwards - can be understood as an extension of his account of mood. In Being and Time, the conditions and structures that explicate there being a world for us are, as said above, 'subjective' in the sense that their description is a description of the mode of being of Dasein: though not themselves psychological, they show up at the 'ontic' level as elements of Dasein, in the way just described for mood. Heidegger's later thought may be regarded as providing a new locus for these conditions, which is in some degree outside Dasein (though not independent of it). Whereas, on the account given in Being and Time, mood is what most basically exposes Dasein to the ontological, in the later Heidegger this role is ascribed to works of art.

\footnotetext{
${ }^{41}$ Being and Time, 182 [Sein und Zeit, 190]. $\quad 42$ Being and Time, 176 [Sein und Zeit, 182].
} 
B. Leiter and M. Rosei Chap03.tex V1 - May 18, 2007 12:02 A.M. Page 101

The Greek 'temple-work', Heidegger says,

opens up a world and at the same time sets this world back again on earth, which itself only thus emerges as native ground... To be a work means to set up a world ... The work moves the earth itself into the Open region of a world and keeps it there... The setting up of a world and the setting forth of earth are two essential features in the work-being of the work. ${ }^{43}$

The distinction between 'world' and what Heidegger calls 'earth' replaces the traditional distinction of form and matter. The work of art makes both possible, and sets them in a relation of 'strife' or opposition to one another. This opening-up of world, and setting-forth of earth, is conceived by Heidegger as something that the work itself does, not as something done by the artist: 'in great art ... the artist remains inconsequential as compared with the work, almost like a passageway that destroys itself in the creative process for the work to emerge. ${ }^{34}$ Nor does the work of art exist for the sake of its audience: our role is to 'preserve' the work, not in a material sense, but in the sense that we, by relinquishing our accustomed ties with the world, abide with the work in order to let it be itself; we enter into relation with the work, for the sake of the work. ${ }^{45}$

Heidegger's statements concerning the world-constitutive role of art invite the question whether they are to be read epistemologically (transcendentally) or ontologically: is the talk of the temple as 'setting up a world' talk of what it allows Dasein to cognize (relate to intentionally), or of an ontological operation? If there is one thing that is clear in the later Heidegger, however, it is that he-in this respect following the German idealists in their attempt to show the 'identity' or mutual implication of being and knowledge-wishes to overcome at the highest level of philosophical reflection the separation implied by this distinction, and that a merely epistemological (transcendental) reading of claims such as those that he makes about the Greek temple does not capture his meaning: 'The art work opens up in its own way the Being of beings. This opening up, i.e., this deconcealing, i.e., the truth of beings, happens in the work. In the art work, the truth of what is has set itself to work. Art is truth setting itself to work. ${ }^{46}$ The temple therefore takes on the transcendental function of Dasein's mood, and with it, the ontological character of Dasein itself. Heidegger's conception is thus more radical than that of Merleau-Ponty, for whom art does no more than represent a transcendental process occurring

\footnotetext{
43 'The Origin of the Work of Art', 42-8 ['Der Ursprung der Kunstwerkes', 28-34].

44 'The Origin of the Work of Art', 40 ['Der Ursprung der Kunstwerkes', 26].

45 'The Origin of the Work of Art', 66-7 ['Der Ursprung der Kunstwerkes', 54-5].

46 'The Origin of the Work of Art', 39 ['Der Ursprung der Kunstwerkes', 25].
} 
B. Leiter and M. Rosen Chap03.tex V1 - May 18, 2007 12:02 A.M. Page 102

within individual subjectivity: in Heidegger the transcendental function is taken to be in some sense enacted in or by the work of art. ${ }^{47}$ Consequently, with Heidegger art is raised to a still higher power than it enjoys in German idealist forms of Philosophical Aestheticism: art does not merely reveal metaphysical truths about the world, instead, or rather in addition, it contributes to (is part of) the world's coming-to-be. The philosophical truth that we glean from art is in fact the truth that art is itself truth, according to Heidegger's understanding of truth as alethea, a unitary disclosing and releasing-into-being of entities.

Heidegger's theory of art illustrates the general principle governing Aestheticist strategies, whereby the strength of the claim made on behalf of the Aesthetic is proportioned to the deficiency alleged in philosophy's ability to execute its task. In the present case, on account of the later Heidegger's assessment of the deep involvement of traditional philosophy with the danger posed by 'technology', the deficiency is considered extreme.

3. Adorno is of all philosophers the most explicitly and intensively concerned with the problem of truth in art, and he insists most strongly that the key to art's value lies in its claim to truth, while also thinking that the notion of art's truth is one of the most difficult to make sense of, and one of the most important problems that philosophy in general is faced with. Adorno's linkage of art and philosophical truth-enshrined in his central theoretical concept of art's 'truth-content' - constitutes a radically original version of the Aestheticist strategy. The term truth-content is meant to affirm the propriety of attributing truth-value to art while acknowledging that works of art themselves are not truth-bearers in an ordinary and straightforward sense: though not themselves true or false, they nevertheless contain truth. The truth-content of a work of art thus consists simply in the truth of whatever it is that the work says concerning the nature of the world in the most general and fundamental, hence philosophical, sense. The complexity lies in Adorno's complex account of how works of art possess truth-content.

In the first place, though committed to a constitutive connection of philosophical knowledge with social criticism, Adorno rejects vehemently the idea that the truth-content of art is something that can be determined on a theoretical, external basis - as for instance naive Marxist art criticism may impute truth to representational art on account of its social verisimilitude or didactic political potential. For Adorno the truth-content of art is aesthetically

\footnotetext{
${ }^{47}$ In the full picture of the later Heidegger, 'language' takes on this role, but the connection with art is preserved through an identification of 'poetry' with ur-language.
} 
B. Leiter and M. Rosen Chap03.tex V1 - May 18, 2007 12:02 A.M. Page 103

realized in the form of the work, and it presupposes the work's autonomy. In part for this reason, on Adorno's account it is above all music that presses, in an exemplary pure form, a claim to truth, with which philosophy should concern itself. Despite the condition that music's truth-content be realized aesthetically - that it be something which one can either succeed in hearing musically or be said to be 'deaf to' 48 - it is not situated by Adorno at the level of the work's primary aesthetic appearance, where Schiller for example would locate it. On the contrary, this level of musical meaning is declared illusory:

The ideological element of music, its affirmative element, does not lie, as with other arts, in its specific content, or even in whether or not its form operates in terms of harmony. It lies merely in the fact that it is a voice lifted up, that it is music at all. Its language is magical in itself, and the transition to its isolated sphere has a priori a quality of transfiguration. The suspension of empirical reality and the forming of a second reality sui generis seem to say in advance: all is well. Its tone is by origin consoling, and to that origin it is bound. But that does not apply unambiguously to music's status as truth... ${ }^{49}$

Achieving the status of truth requires further moments, in which this first moment - called by Adorno 'aesthetic semblance', which he thinks belongs to the 'ideological', 'affirmative', transfigurative level at which we are told, falsely, that 'all is well' - is overcome. ${ }^{50}$ The truth-content of art involves, Adorno supposes, a (non-sensuous, yet aesthetically realized) operation on aesthetic semblance, namely, a negation of the affirmation expressed in aesthetic semblance: we so to speak hear the music pass judgement on its own beauty, exposing it as untrue, as not reflecting how things truly are. This undoing of the message given out by aesthetic semblance is at the same time a criticism of the existing world order: 'Its depth is that of a judgement pronounced against the negative aspects of the existing world. The basis for judgement in music, as a cognitive force, is aesthetic form ... In the cognitive act performed by art, the artistic form represents a criticism' of existing reality; ${ }^{51}$ art negates 'the categorial determinations stamped on the empirical world'. ${ }^{52}$ This idea is followed out in Adorno's brilliant, whether or not correct,

${ }^{48}$ Beethoven, 171 [Beethoven, 246]. $\quad{ }^{49}$ Beethoven, 6-7 [Beethoven, 25-6].

50 Art's truth-content is something that 'appears aesthetically', but that the work bears 'beyond aesthetic semblance': 'What is beyond the semblance of what appears is the aesthetic truth content: that aspect of semblance that is not semblance' (Beethoven, 172 [Beethoven, 247]).

51 Philosophy of Modern Music, 125 [Philosophie der neuen Musik, 119].

52 Aesthetic Theory, 5 [Ästhetische Theorie, 15]. Art 'seeks to aid the nonidentical', which is repressed by the compulsion to identity: see Aesthetic Theory, 4 [Ästhetische Theorie, 14]. 


\section{B. Leiter and M. Rosen Chap03.tex V1 - May 18, 2007 12:02 A.M. Page 104}

interpretations of particular artists and works-his account, for instance, of the inexpressive fracturedness of Beethoven's late style and the calculated alienation of his Missa Solemnis, ${ }^{53}$ and of how Schoenberg's negation of aesthetic semblance allows perception of 'untransfigured suffering'. ${ }^{54}$ (Also illustratively relevant is the 'taking back' of Beethoven's Ninth by Adrian Leverkühn, the fictional composer in Thomas Mann's Adorno-influenced Doctor Faustus: after witnessing the death of a child, Leverkühn pronounces that the all-affirming humanistic Ninth ought not to be, and to this end composes his great 'Apocalypsis'.)

Bound up with this second, negative moment is a third, positive moment: art's indication of the 'non-absolute aspect' of existing reality and of the 'possibility of reconciliation', and thus its articulation of 'authentic hope'. ${ }^{55}$

In describing truth-content as involving this complex conjunction of three moments - ideological-transfigurative, negative-critical, and hope-sponsoring-Adorno is in a sense simply taking seriously the common idea that musical structure is akin to argumentation. Regarding the 'how' of musical negation and affirmation, this remains ultimately ungraspable: while musicological analysis has a contribution to make, the means by which music negates and affirms cannot be spelled out-music has necessarily an 'enigmatic' quality and its enigma 'cannot be solved'. ${ }^{56}$ Aesthetic Theory, $122 \mathrm{ff}$. [\#̈sthetische Theorie, $182 \mathrm{ff}$ ] judgemental import defies analysis, a limit is reached regarding what Adorno can say by way of explicating the concept of artistic truth-content in positive philosophical terms, indispensable though it remains for the theory of art. All that can be done at this point is to turn to concrete musical examples and their interpretation.

Adorno's reason for thinking that the negation of the world order and correlative articulation of authentic hope requires art and is unavailable in its full import outside it, lies in his general critical theory of reason as bound (by its conceptuality) to an instrumental, repressive, ideological function. This thesis plays in Adorno's Aestheticist strategy the role played in MerleauPonty by the critique of objective thought and in Heidegger by the critique

\footnotetext{
53 Beethoven, 123-53 [Beethoven, 180-222].

54 Philosophy of Modern Music, $29 \mathrm{ff}$. [Philosophie der neuen Musik, $34 \mathrm{ff}$.].

55 Beethoven, 172 [Beethoven, 247]. The account given here is simplified, in so far as Adorno's account of music's truth-content is not uniform: what it amounts to exactly depends on which musical era (e.g., Beethoven or Schönberg) is in question.

56 Aesthetic Theory, $122 \mathrm{ff}$. [̈̈sthetische Theorie, $182 \mathrm{ff}$.].
} 
B. Leiter and M. Rosen Chap03.tex V1 - May 18, 2007 12:02 A.M. Page 105

of traditional ontology, of setting limits to what philosophy can achieve by discursive means and thereby preparing the context for Aesthetic insight. The element of 'authentic hope' that Adorno locates in the work's truth-content can have no discursive validation, for the reason that, on Adorno's account, no rational grounds can be given for anything but despair or melancholy.

Adorno's Aestheticist strategy both presupposes and subjects to critique the Philosophical Aestheticism of the German philosophical tradition. Schiller's claim that art aims at human emancipation, the Romantic programme of magical idealism, Hegel's claim that art realizes the Idea-all these ideas are accepted by Adorno, in the sense that, he agrees, they do indeed correspond to the telos which art, by virtue of its aesthetic semblance, projects. What sets Adorno apart from his predecessors is his conviction that the realizability of this telos, with its incorporated claim that suffering is redeemable, is, for us now, unintelligible. Hence the falsity of (idealist) philosophies of art that promise more than reality can deliver, and the predominantly negative character of the truth-content of art. Hence, also, Adorno's esotericism-the strong suggestion that the 'audibility' (visibility, etc.) of the truth content of an artwork presupposes a philosophically informed consciousness, one that has passed through (and gone beyond) German idealism. ${ }^{57}$

4. That it should be possible for three philosophies as diverse and conflicting as those of Heidegger, Adorno and Merleau-Ponty nonetheless to concur in regarding art as, in Schelling's words, a 'document and organon' of philosophy, testifies to the appeal and versatility of the Aestheticist strategy.

Claims concerning the transcendence of philosophy by art and affect continue to be made in present-day Continental philosophy. They are of course not all of a piece, but typically they have an orientation which differs importantly from that of the three twentieth-century philosophers just discussed, and which reflects the influence of deconstruction. The radical critiques of rationality offered in deconstruction go beyond what is attempted in Merleau-Ponty, Heidegger, or Adorno, whose intention in criticizing objective thought, traditional ontology, and identity thinking, is to contest an entrenched philosophical paradigm, but not philosophical thought as such;

\footnotetext{
57 Thus in some places Adorno suggests that the truth-content of art comes to light fully only through the mediation of philosophical commentary (which is not the same as saying that this commentary takes over its truth-content). It will be clear from what has been said that Adorno's form of Philosophical Aestheticism, to the extent that it may be estimated apart from his philosophy as a whole, is less epistemologically robust than those discussed earlier, in so far as the heavy burden that Adorno asks art to carry rests on super-fine conditions.
} 


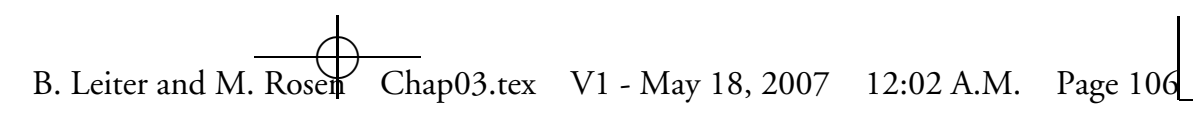

106

PHILOSOPHICAL AESTHETICISM

for which reason these thinkers, though relatively closer than the German Romantics to Aesthetic Subversivism, remain distinct from it.

In thishyper-critical context, it is not surprising that themes in philosophical Romanticism should have been picked up on, ${ }^{58}$ but there is a deep difference of Philosophical Aestheticism from deconstruction which it is crucial to keep in view in order that the former should not be exposed to criticism drawn by the latter. Philosophical Aestheticism seeks to interpret in philosophically coherent terms the features of the Aesthetic that, the Platonist believes, make art indifferent or inimical to reason, and thereby to exhibit their true rationality; deconstructionist appropriations of art and affect insist, by contrast, in a Platonic way but to anti-Platonic ends, on the irreconcilable antagonism of reason and the Aesthetic. Deconstruction of this species therefore crosses the line between a philosophically grounded elevation of the Aesthetic designed to complement and extend philosophical reflection, such as Philosophical Aestheticism provides, to a philosophically ungrounded critique of philosophy from the standpoint of the Aesthetic.

When the Aesthetic is conscripted in opposition to philosophy in the deconstructionist manner, we have what was called earlier the Subversive view of the relation of art to philosophy. Such a view, where the Aesthetic is as if credited with a rationality, or 'logic', of its own, one that at no point joins up with ordinary or philosophical discursive reason, is hard to interpret. The problem lies in seeing how this Aesthetic (anti-)rationality can be recognized as such. If the opposition of the Aesthetic to philosophy is held to be total and unmediated, i.e. not an opposition that can be so much as stated within philosophy, but rather an opposition of philosophy to something which is absolutely 'other' to it, then it is not thinkable as an opposition. If on the other hand the opposition is philosophically mediated, then it seems that the moment which the Aesthetic is held to represent is really a further moment of philosophy. In the former case, the Aesthetic protest against philosophy seems mute and contentless; in the latter, the Aesthetic seems reduced to a mere cypher for discursive philosophical claims, i.e. it is instrumentalized in the very way that, Subversivists typically object, traditional, 'dogmatic' philosophy of art has done. The point to be grasped, in any case, is the logical distance of this scenario from that of Philosophical Aestheticism. The suspicion must be, furthermore, that Aesthetic strategies in deconstruction trade off the authority

\footnotetext{
58 See Lacoue-Labarthe and Nancy, The Literary Absolute, for an example of deconstructionist reading of German Romanticism.
} 
B. Leiter and M. Rosen Chap03.tex V1 - May 18, 2007 12:02 A.M. Page 10خ

of the Aesthetic that philosophical Romanticism established historically, while undermining the qualified affirmation of philosophy's claim to systematic knowledge which was required to create that authority. ${ }^{59}$

\section{Critics of Philosophical AESTHETICISM}

Individual instances of Philosophical Aestheticism can, of course, be evaluated only in the context of the philosophical position to which they belong. As regards the strategy itself, the historical discussion in the last two sections bears out, I suggest, the contention in Section 1 that Philosophical Aestheticism is in principle coherent and defensible, within the context of a broadly transcendental, non-naturalistic conception of the task of philosophy, where understanding is sought of the world's non-empirical constitution or comingto-be. Philosophical Aestheticism represents, I have also tried to suggest, the strongest claim that can be made coherently on behalf of the idea that the Aesthetic contributes to the task of philosophy; any stronger claim will either result in epistemological irresponsibility (Jacobi), or run into logical difficulty (Aesthetic Subversivism).

Two figures in the history of post-Kantian philosophy, Hegel and Sartre, are of particular interest from the point of view of arriving at a balanced critical assessment of Philosophical Aestheticism. It will be instructive to consider briefly their reasons for rejecting the notion that the Aesthetic enjoys cognitive privileges.

1. Hegel's relation to Philosophical Aestheticism is complex. On the one hand, Hegel appears to fall in line with his Romantic contemporaries when he includes art among the forms of 'absolute' spirit: by characterizing art as the realization of the Idea in sensuous form, a unity of form and content that may be taken as an expression of freedom and a presentation of the absolute, Hegel accepts the Romantic characterization of works of art as concerned with the relation, which it is the task of philosophy to grasp, of the finite to the infinite. What cancels the seeming consequent commitment to at least Aesthetic Parallelism, if not to Philosophical Aestheticism, is Hegel's crucial

\footnotetext{
${ }^{59}$ For an extended critique of what I have been calling Aesthetic Subversivism, see Megill, Prophets of Extremity.
} 
B. Leiter and M. Rose巾 Chap03.tex V1 - May 18, 2007 12:02 A.M. Page 108 108

historical qualification, that art is no longer 'the highest mode' of truth but has 'has lost for us genuine truth' ${ }^{60}$ Philosophical Aestheticism, on Hegel's account, is a misguided attempt to take up in contemporary philosophical self-consciousness an attitude which can be ascribed to historically earlier shapes of consciousness but which it is impossible to adopt for us in the present tense. Art has, Hegel accepts, served to project the unity of finite and infinite, but he denies that we now can regard a sensible appearance as incarnating the Idea. Art's loss of import leaves no cognitive deficit, however, because the need to which it once answered, philosophy shows, has been fulfilled. The Romantics' formulation of the concept of Aesthetic cognition comes too late, when there is nothing more for us to learn philosophically from art.

Hegel's grounds for maintaining this position derive from his broader opposition, spelled out in numerous contexts, to claims of feeling and immediacy. ${ }^{61}$ Hegel grants that all productions of thought should, upon completion, become matters of feeling, as in the moral consciousness of a fully formed ethical agent. What he denies is that there can be more original content in feeling than in thought, in particular, elevated content of the sort claimed in Jacobi's theory of Gefühl and in Schleiermacher's account of religion. Hegel's argument is that feeling, because its form is that of mere immediacy, particularity, and subjectivity, is by its nature incapable of bearing the kind of universal content claimed by Romantics. Further, Hegel argues that if religion for instance is allowed to become a matter of feeling, then, absurdly, so may everything, and that in any case the pressure to ground belief on feeling dissolves when it is grasped that the limits of mere finite understanding are not those of philosophical reason. What Aestheticism mistakes for $\mathbf{a}_{\mathbf{\lambda}}$ content of feeling is in fact, Hegel claims, a completed product of reason that has passed over into the form of feeling. ${ }^{62}$

${ }^{60}$ Aesthetics: Lectures on Fine Art, vol. i, Introduction, p. 103 and p. 11 [Vorlesungen über die Ästhetik, xiii. 140 and 24]. Hegel's well-known but enigmatic thesis that art is at an end, at least with respect to its highest vocation, is found at: pp. 9-11 [xiii. 21-5]; Introduction to Part 1, 'Position of art in relation to the finite world and to religion and philosophy', esp. pp. 101-3 [xiii. 138-41]; and 'The end of the romantic form of art', pp. 602-11 [xiv. 230-41].

61 See Philosophy of Mind, $\$ \$ 446-8$, pp. 192-8 [Philosophie des Geistes, 245-52]; 'Foreword to Hinrichs', $346 \mathrm{ff}$. ['Vorrede zu Hinrichs' Religionsphilosophie', $55 \mathrm{ff}$.]; and Encyclopaedia Logic, $\$ \$ 61-78$, pp. 108-24, 'Third position of thought with respect to objectivity: immediate knowing' [Logik, 147-67].

62 The tradition of criticism descending from Hegel, which includes Carl Schmitt and Georg Lukács, in which the Romantic emphasis on art and the affective is interpreted as irrationalist and an index of conceptual deficiency, is discussed in Bohrer, Die Kritik der Romantik, pt. II. A striking restatement, 
B. Leiter and M. Rosen Chap03.tex V1 - May 18, 2007 12:02 A.M. Page 109

2. Whereas Hegel treats Philosophical Aestheticism as a philosophical error, deriving from attachment to an inferior shape of rationality in the development of spirit, Sartre locates its origin in ordinary consciousness, in the a priori motivational dynamics of the individual subject. Discrediting the truth-claims of art and affect is a central motive of Sartre's early studies of emotion and imagination. Both of these modes of consciousness emerge from Sartre's analyses as, in effect, forms of self-deception. The essence of emotion consists, Sartre argues, in its phenomenological transformation of the subject's world, and the constant meaning of emotional transformations, he proposes, is to deny the existence or bury awareness of some respect in which the world poses a difficulty for the subject. The point of affect is to endow objects with qualities which reconfigure the world in such a way as to bring it into conformity with our wishes, 'as though the relations between things and their potentialities were not governed by deterministic processes but by magic. ${ }^{63}$ Imagination, similarly, presupposes a negation of reality: the act of imagination 'is a magical act. It is an incantation destined to make the object of one's thought, the thing one desires, appear in such a way that one can take possession of it. ${ }^{64}$ The impossibility of art's having cognitive significance follows directly: art presupposes imaginative consciousness, and so is premised on a rupture with the real world in favour of unrealities; because the work of art is 'an irreality', ${ }^{65}$ so too are beauty and all the other qualities that art bestows on its objects - 'the real is never beautiful'. ${ }^{66}$ The concealed aspiration of art is to relocate subjectivity outside the world, to become God-like, in denial of one's project and radical freedom. ${ }^{67}$ This holds, according to Sartre, for all of the arts that presuppose the 'poetic attitude', which include poetry, music, and painting; only prose literature, he argues, declines to exploit the unreal

and updating, of Hegel's anti-Romantic position is found in Pippin, 'What Was Abstract Art? (From Hegel's Point of View)'.

${ }^{63}$ Sketch for a Theory of the Emotions, 63 [Esquisse d'une théorie des émotions, 33]. Being and Nothingness shifts partially away from this standpoint, in so far as some instances of affective consciousness are interpreted, in line with Heidegger, as ontological cognitions: see pp. 29-33 [L'être et le néant, 64-9] and p. 464 [520] on anguish (which 'manifests our freedom to our consciousness'), and pp. 288-9 [335-6] on shame ('the original feeling of having my being outside, engaged in another being'). But the official line remains as it was in the Sketch: see pp. 444-5 [499-500], reaffirming the 'magical' nature of affect.

64 The Imaginary, 125 [L'Imaginaire, 161]. $\quad 65$ The Imaginary, 188 [L'Imaginaire, 239].

66 The Imaginary, 193 [L'Imaginaire, 245].

67 What is Literature?, 9-10 [Qu'est ce que la littérature?, 68-70]. See also however pp. 23-4 n. 4 [85-7 n. 4], where some trace of a different view is to be found. The theme of art's 'mystification' and 'transcendental' illusoriness - its being 'really a magical attempt to satisfy desire' - is resumed and elaborated in the Notebooks for an Ethics, 551-4 [Cahiers pour une morale, 566-70]. 
B. Leiter and M. Rosen Chap03.tex V1 - May 18, 2007 12:02 A.M. Page 110

and expresses an existential stance consistent with human freedom. To set cognitive store by art, as Philosophical Aestheticism affirms that we should, is therefore to engage in an intentional falsification of reality and to negate human freedom.

3. The grounds on which Hegel and Sartre criticize Philosophical Aestheticism go back, in a sense, to Kant. Hegel's basic complaint is that Philosophical Aestheticism flouts the Kantian condition of conceptuality that cognition stands under, while Sartre's repudiation of art and affect as illusory modes of consciousness is a reaffirmation of the original, austere Kantian conception of the conditions for freedom, which Philosophical Aestheticism is viewed as undermining. Both are open to challenge. Hegel's objection of epistemological irresponsibility has force only against an Aestheticist position like Jacobi's, which makes Gefühl a general criterion of knowledge. The objection that Aestheticism evades the demands of conceptuality is not a straightforward matter, to be settled by a direct appeal to Kant's Transcendental Deduction. Hegel's own claim that philosophy has come to appreciate the comprehensiveness of conceptuality in a sense that leaves no shortfall in the power of philosophical discourse to express truth, for which art or anything else would be required to compensate, requires that this comprehensiveness be demonstrated; to that extent, his criticism of Philosophical Aestheticism presupposes his Logic. Sartre's anti-Aestheticism, for its part, promises to return us to the much-criticized Kantian dualism of freedom and nature. For as long as a question-mark hangs over the alternatives, the Aesthetic turn in post-Kantian philosophy may be claimed to hold its own.

4. Criticism of a different sort, taking the form of a charge of conceptual or logical confusion, has come from aestheticians with an analytic orientation. Thus, in a detailed critical study of the German aesthetic tradition, it has been claimed by Jean-Marie Schaeffer that the distortions (as he sees them) of the 'speculative theory of Art' are founded on a 'category error', compounded by a decision to 'sacralize' profane reality, ${ }^{68}$ much as, very much earlier, I. A. Richards had argued that 'Revelation Doctrines' of literary art are rooted in a confusion of referential and emotive language use. ${ }^{69}$ The weakness of such external criticism lies in the difficulty it faces in demonstrating non-circularly the methodological failing it alleges in Philosophical Aestheticism and its tendency simply to disregard the motivation Aestheticism lays claim to. For

68 Art of the Modern Age, 64; see also pp. 12-13, 273.

69 The Principles of Literary Criticism, chs. 32-5. 


\section{B. Leiter and M. Rose\# Chap03.tex V1 - May 18, 2007 12:02 A.M. Page 111}

example, Schaeffer's claim that the speculative theory errs in so far as it 'treats art as a specific ontic domain by virtue of its value ${ }^{30}$ hardly succeeds in showing a confusion unless a negative thesis concerning the ontological non-significance of value is assumed $;^{71}$ the alleged mere 'decision to sacralize' is, from another angle, an axiological discovery. Similar remarks - to the effect that what presents itself as a logical criticism turns really on disputed matters of doctrine-apply to Richards' (undisguised) reliance on the assumption that knowledge is necessarily discursive, indeed coextensive with natural science. ${ }^{72}$

\section{THE CONTEMPORARY PERSUASIVENESS of Philosophical Aestheticism}

In view of the remoteness of the philosophical preconditions of Philosophical Aestheticism from the basic, predominantly naturalistic working assumptions of much current anglophone philosophy, it is appropriate to raise the question of the strength of its claim to attention outside the sphere of Continental philosophy.

In the first instance it is clear that there can be no question of undermining or weakening, let alone refuting, the naturalistic outlook which stands opposed to Philosophical Aestheticism through a direct appeal to the phenomena - any description of the phenomena substantial enough to count as 'evidence' against naturalism will be gravely tendentious. However, this still leaves another task in view, namely to show that Philosophical Aestheticism has plausibility from the standpoint of one whose philosophical commitments are (to the extent that this is possible) neutral as between naturalism and transcendentalism, ${ }^{73}$ and on this score there are various things to be said, centred on two connected

70 Art of the Modern Age, 64.

71 Genette, in The Aesthetic Relation, Introduction, approves Schaeffer's conclusions, adding that the speculative theory mistakes the proper function of aesthetics, which is not called upon either to justify or excoriate the aesthetic relation; its function is, if possible, to define, describe, and analyze it' (p. 5) - a thesis which again circumscribes philosophy of art in a way unacceptable to Philosophical Aestheticism.

72 Further criticism of Philosophical Aestheticism may be found in Geuss, Outside Ethics, essays 11-12. Geuss presents his negative verdict regarding what he calls 'Romantic common sense' in company with a strongly anti-realist, Nietzschean view of value, and to that degree his criticisms are external to the transcendental programme.

73 This is perhaps how Gadamer's project in Truth and Method, pt. I, 'The question of truth as it emerges in the experience of art', should be understood, i.e. as arguing from the experience of art to 
B. Leiter and M. Rose Chap03.tex V1 - May 18, 2007 12:02 A.M. Page 112

ideas: that there is a natural route to be plotted from the pre-philosophical interior of aesthetic experience towards transcendentalism, and that, unless art is thought about in a transcendental light, the value which we ascribe to it cannot be fully accounted for. I will begin with the second.

1. Appeals to 'our' conception of the value of art encounter inevitably the initial complication that no view of art which is free of the rich and complex cumulative history of reflection on art, a history which exhibits (if we take the full span from classical times to contemporary post-modernism) much greater diversity than reflection on moral matters, can be pinned on a wouldbe naive, pre-philosophical natural consciousness. Nor even should it be supposed that there is any unitary view of art that we can collectively selfascribe - most probably the 'folk' view of art of late modernity is fragmented and inconsistent. ${ }^{74}$ Yet, allowing that the ideas of 'common sense' concerning art's value are infected by Romanticism (just as they are by scientism, a reminder that the difficulty affects all sides), there is overwhelming evidence that the idea that art is a privileged source of the deepest and most important truths represents at least one, central and abiding component of the folk understanding of art in late modernity. ${ }^{75}$ Our practice of setting a special kind of value on the experience of art, and our attribution to it of an elevated spiritual authority, which would have appeared bizarre and irrational to many earlier ages, is not self-justifying and prima facie makes no sense if art is cognitively impotent. This is Adorno's deep insight: that in so far as engagement with art is distinguished from consumption or entertainment, it is impossible to take works of art in any other way than as saying how things are; cognitivity, though not among the manifest primary characteristics on the basis of which entities are distinguished as works of art, is a necessary, teleological condition on artistic validity; the experience of beauty impresses us

the possibility of a kind or mode of truth which falls outside the scope of natural science, although Gadamer also allows himself to be read more ambitiously (and less plausibly) as attempting to overturn natural science's claim to a monopoly on truth by an appeal to art.

${ }^{74}$ For which reason the Hegelian objection that Philosophical Aestheticism is at odds with modernity as such expresses at most a half-truth: see, e.g., Bürger, Zur Kritik der idealistischen Ästhetik, esp. pp. 17-25 and 87-90, and Genette, The Aesthetic Relation, 4. This criticism is especially weak when unsupported by a comprehensive theory of modernity such as Hegel himself offers.

75 'A painting is a statement of the artist's notions of reality in the terms of plastic speech. In that sense the painter must be likened to the philosopher rather than to the scientist' (Rothko, The Artist's Reality, 22). Illustrations from the writings of artists and critics could be multiplied indefinitely. Distinguished expressions of the idea include Fry's statement of the 'metaphysical hypothesis' regarding the significance of 'significant form' in chapter 3 of Art, Sullivan's description of our expectation regarding art's relation to reality in Beethoven, bk. I, ch. 1, and Steiner's evocation of the experience of literary meaning in Real Presences. 
B. Leiter and M. Rosen Chap03.tex V1 - May 18, 2007 12:02 A.M. Page 113

as having importance, and this claim cannot be got to stand without ascribing to beauty the import of an act of judgement. Approximately the same thought was articulated by Schiller in a letter to Goethe deploring the return to a neo-classical aesthetics:

I think that recent analysts, in their struggle to separate out the concept of beauty and present it in a certain purity, have almost hollowed it out and turned it into an empty sound, and that the opposition between the beautiful and the true or correct has been taken much too far... I should like somebody to venture to dismiss from circulation the concept and even the word beauty, to which all those false notions are attached inseparably, and, as is proper, to set up in its place truth in the fullest sense of the word. ${ }^{76}$

This then raises the questions: can art's claim to truth be understood in naturalistic terms $\bar{s}_{\bar{\beta}}$ or can it be redeemed only through transcendentalism for some other 'metaphysical' position)? And, if naturalism cannot underwrite art's claim to truth, can it nevertheless offer an adequate account of the value of art?

While there is no space here for a proper discussion, some brief points may be made suggesting that a detailed examination of naturalistic aesthetics is likely to return a negative answer to both questions. To the extent that we take our bearings from the results of analytic aesthetics - which, to be sure, is not as such committed to philosophical naturalism, but with which, as indicated previously, it typically shares the presently relevant assumptions - there are good grounds for doubting that any reconstruction of artistic truth which grants it more than an incidental connection with the value of art can emerge. ${ }^{77}$ The tendency of empirically orientated inquiry is to locate artistic 'truth' at the level of sense rather than reference, i.e. in the presentational or 'illustrative' power of art (art makes vivid, gives a feeling of actuality, represents things in emotion-arousing ways, etc.), or to identify art-based cognition with interpersonal tourism (fictional art allows us to take up foreign points of view), and neither of these functions is in any way unique to art, or cannot be performed just as well or better by historical and biographical writing, documentary film-making, face-to-face conversation, etc. This is furthermore a conclusion that analytic aestheticians themselves have come to: John Passmore, pursuing the question whether we have grounds for taking art as seriously as we do and considering cognitivity as a candidate, concludes

76 Letter to Goethe, Jena 7 July 1797, in Briefe 1796-98, no. 104, p. 98.

77 For a recent attempt to make the connection more than incidental, see Young, Art and Knowledge. 


\section{B. Leiter and M. Rosen Chap03.tex V1-May 18, 2007 12:02 A.M. Page 114}

that little more can be said than that art may focus attention in ways that prove cognitively fruitful, while Jerome Stolnitz emphasizes the embarrassing banality of the propositionally articulated 'truths' that literary works of art may be said to communicate. ${ }^{78}$ The likely result of empiricist aesthetics, therefore, is that talk of 'artistic truth' either falls away, or reduces to the sincerity or self-expressive achievement of the artist, or serves as an infelicitous way of referring to the formal unity or some other non-cognitive merit of the artwork.

If so, naturalistically orientated aesthetics, to the extent that it accepts the challenge of accounting for the value of art in general (a question which for a long time, precisely on account of its historical association with 'metaphysical' systems, remained off the agenda of analytic aesthetics), is bound to interpret the value of art apart from any idea of a cognitive vocation. While here again no survey of the field is possible, it is fair to say that the basic thrust of analytic accounts of art's value has been, unsurprisingly, towards a broadly affective, Humean view. ${ }^{79}$ The point to make accordingly is that dissatisfaction with such accounts - which revise the ordinary understanding of aesthetic experience by, among other things, making the aesthetic subject's mental state bear the value that the subject herself ascribes to the aesthetic object-is the systematic as well as historical starting point of anti-empiricist, transcendental theories of the aesthetic. ${ }^{80}$

2. The second idea which, I said, can be pursued in support of Philosophical Aestheticism is that aesthetic experience tends by nature towards transcendentalism.

It is generally agreed that aesthetic experience exhibits the following characteristics: (i) Rupture with the attitude ordinarily entertained towards the world, leading traditional theorists to posit a special kind of 'disinterestedness', 'aesthetic attitude', 'psychic distance', etc., as the mark of the aesthetic. (ii) Apprehension of distinctive unity, in the sense that the aesthetic object is experienced as exhibiting a special kind of wholeness, naturally glossed in 'organic' terms, whereby whole and parts stand in a relation of mutual explanation and exist for the sake of one another. (iii) Fusion of fact and value, in the sense that the aesthetic object is experienced as saturated with value, and value is

\footnotetext{
78 Passmore, Serious Art, chs. 6-7, and Stolnitz, 'On the Cognitive Triviality of Art'.

79 For an exceptionally thorough statement of a naturalistic conception of aesthetic value, see Railton, 'Aesthetic Value'.

${ }^{80}$ It is also to be observed that, the more naturalistic theories of the aesthetic fill themselves out in the attempt to do art full justice, the weaker their naturalistic commitment becomes: Dewey's endeavour in Art and Experience to forge a conception of 'experience' adequate to elucidate aesthetic value, for example, moves in the direction of German idealism.
}

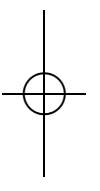


B. Leiter and M. Rosen Chap03.tex V1 - May 18, 2007 12:02 A.M. Page 115

accordingly experienced as 'real', 'present', 'immediately given', etc.; value figures phenomenologically in aesthetic experience as a kind of object, as part of what-is-experienced, not merely an attribute of the subjective upshot that results from the encounter with the object.

Now while the existence of experience which is taken to have these properties is by no means inconsistent with naturalism-empirical-psychological, evolutionary, etc., explanations of the human organism's disposition to represent certain objects in the aesthetic way are entirely possible - the point to be emphasized is that the structure of the experience is itself non-naturalistic: when objects are experienced aesthetically, they are experienced in a way that differs from and is inconsistent with the naturalistic way in which empirical objects are (centrally, if not exhaustively) ordinarily experienced. Though aesthetic experience does not involve the application of a conceptual scheme, if a conceptual scheme were to be articulated on its behalf, it would not be naturalistic: the 'implicit conceptual scheme' of aesthetic experience would correspond to a world governed by final not efficient causality, in which the distinction of empirical from evaluative properties, the realism of the natural attitude, and empirical determinacy itself are all broken down, and to whose contents the subject is related as something other than a further, causally enmeshed empirical item. As Schiller formulates this idea more specifically in his Letters, artistic form is autonomy, the freedom which cannot be found in nature. ${ }^{81}$ At the same time, the non-naturalistic form or 'conceptual scheme' of aesthetic experience is proto-transcendental - the 'invitation in art' so often spoken of is, among other things, an invitation to transcendental philosophy. Hence the suggestion of Fichte (and Schopenhauer) that the aesthetic and transcendental standpoints are not simply analogous, but that aesthetic experience is itself an instance of taking the transcendental turn, an intuitive enactment or phenomenological realization of the conceptual shift from pre-Copernican philosophy and common-sense realism to the plane of transcendental reflection. ${ }^{82}$

There is a further and important connection with the earlier idea that truth is a condition on artistic value. The developments in transcendental philosophy

\footnotetext{
81 And Adorno: 'Music recognises no natural law; therefore, all psychology of music is questionable' (Philosophy of Modern Music, 32 [Philosophie der neuen Musik, 37]).

${ }^{82}$ Closely connected is the way in which the experience of art resists explanation in terms of the schemata of common-sense psychology-aesthetic response is not a case of coming to believe, desire-satisfaction, perception, emotional reaction, symbol comprehension, etc.; responses that can be explained on these familiar patterns belong, for all the good reasons given by Collingwood, to the sphere of craft and not art. Hence the standard resort to the catch-all category of 'imagination'.
} 
B. Leiter and M. Rose巾 Chap03.tex V1 - May 18, 2007 12:02 A.M. Page 11d

after Kant that ascribe philosophical significance to the Aesthetic involve a reaction against the sharp differentiation of modes of validity (theoreticalcognitive, practico-moral, aesthetic) that results from Kant's Critiques, in favour of the idea that these are but different 'moments' of a single, unified, underlying mode of validity. Now this pursuit of 'higher unity of reason' again receives a warrant from the interior perspective of aesthetic experience, which as it were - that is, in so far as we again speak on its behalf-denies the absoluteness of Kant's differentiation by affirming the identity of the True, the Good, and the Beautiful: the integrity and comprehensiveness of aesthetic experience resists the idea that truth is irrelevant to and can be disentwined from a supposedly 'purely aesthetic', non-cognitive mode of validity. (For which reason post-Kantian idealists were drawn to the idea that the aesthetic is not just one member-branch of human reason, but that it is, or anticipates, the point in human reason at which all of its branches are united.) In this light, an explanation of the aesthetic in naturalistic terms will be necessarily, once again, a sideways-on explaining away, which imputes error to the consciousness it explains.

That there are limits to what naturalism can make of art, and that there is an elective affinity of aesthetic experience with transcendental reflection, is not sufficient to justify Philosophical Aestheticism, since Aesthetic Parallelism is equally consistent with those conclusions. It does, however, take us to the point where the Aestheticist strategy can begin to be argued for. ${ }^{83}$

\section{REFERENCES}

Adorno, Theodor W., Aesthetic Theory, trans. and ed. R. Hullot-Kentor (London: Athlone Press, 1997) [Ästhetische Theorie, Gesammelte Schriften, vii, ed. Gretel Adorno and Rolf Tiedemann (Suhrkamp: Frankfurt am Main, 1970)].

Beethoven: The Philosophy of Music: Fragments and Texts, trans. Edmund Jephcott, ed. Rolf Tiedemann [Beethoven: Philosophie der Musik: Fragmente und Texte, in Nachgelassene Schriften, ed. Theodor W. Adorno Archiv, Abt. 1, Bd. i, ed. Rolf Tiedemann (Frankfurt am Main: Suhrkamp, 1970)].

${ }^{83}$ For further discussion of the figures and themes discussed in this chapter, in addition to works already referred to, see the following: Bowie, Aesthetics and Subjectivity and Romanticism and Critical Theory; Crowther, Art and Embodiment; Eldridge, The Persistence of Romanticism; Geuss, 'Art and Theodicy'; Hammermeister, The German Aesthetic Tradition; Redding, The Logic of Affect; and Zuidervaart, Artistic Truth. 
B. Leiter and M. Rose Chap03.tex V1 - May 18, 2007 12:02 A.M. Page 11九

Philosophy of Modern Music, trans. Anne G. Mitchell and Wesley V. Blomster (New York: Continuum, 2003) [Philosophie der neuen Musik, rev. edn. (Frankfurt am Main: Europäische Verlagsanstalt, 1958)].

Beiser, Frederick C., The Fate of Reason: German Philosophy from Kant to Fichte (Cambridge, Mass.: Harvard University Press, 1987).

German Idealism: The Struggle against Subjectivism, 1781-1801 (Cambridge, Mass.: Harvard University Press, 2002).

The Romantic Imperative: The Concept of Early German Romanticism (Cambridge, Mass.: Harvard University Press, 2003).

Beiser, Frederick C., Schiller as Philosopher: A Re-Examination (Oxford: Clarendon, 2005).

Bernstein, J. M., The Fate of Art: Aesthetic Alienation from Kant to Derrida and Adorno (Cambridge: Polity, 1992).

Bohrer, Karl Heinz, Die Kritik der Romantik (Frankfurt am Main: Suhrkamp, 1989).

Bowie, Andrew, Aesthetics and Subjectivity: From Kant to Nietzsche (Manchester: Manchester University Press, 1990).

Romanticism and Critical Theory: The Philosophy of German Literary Theory (Manchester: Manchester University Press, 1990).

Bubner, RüDIGER, Ästhetische Erfahrung (Frankfurt am Main: Suhrkamp, 1989).

Crowther, Paul, Art and Embodiment: From Aesthetics to Self-Consciousness (Clarendon: Oxford, 1993).

Bürger, Peter, Zur Kritik der idealistischen Ästhetik (Frankfurt am Main: Suhrkamp, 1983).

Dewey, John, Art as Experience (New York: Minton, Balch \& Co., 1934).

Eldridge, Richard, The Persistence of Romanticism: Essays in Philosophy and Literature (Cambridge: Cambridge University Press, 2001).

Fichte, J. G., The System of Ethics, ed. Daniel Breazeale and Günter Zöller (Cambridge: Cambridge University Press, 2005) [Das System der Sittenlehre nach den Prinzipien der Wissenschaftslehre (1798), in Johann Gottlieb Fichtes sämmtliche Werke, ed. Immanuel Hermann Fichte (Berlin: Walter de Gruyter, 1971), iv. 1-365].

Frank, Manfred, The Philosophical Foundations of Early German Romanticism, trans. Elizabeth Millán-Zaibert (Albany, NY: State University of New York Press, 2004) ['Unendliche Annäherung': Die Anfänge der philosophischen Frühromantik (Frankfurt am Main: Suhrkamp, 1997), pt. III].

Gadamer, Hans-Georg, Truth and Method, 2nd rev. English edn., trans. Joel Weinsheimer and Donald G. Marshall (London: Sheed \& Ward, 1993) [Wahrheit und Methode: Grundzüge einer philosophischen Hermeneutik, 6. Auflage, in Gesammelte Werke, i (Tübingen: Mohr, 1990)].

Genette, Gérard, The Aesthetic Relation, trans. G. M. Goshgarian (Ithaca, NY: Cornell University Press, 1999) [L'Oeuvre de l'art. La relation esthétique (Paris: Seuil, 1996)].

Geuss, Raymond, 'Art and Theodicy', in Morality, Culture, and History: Essays on German Philosophy (Cambridge: Cambridge University Press, 1999), 78-115. Outside Ethics (Princeton: Princeton University Press, 2005). 
B. Leiter and M. Rose Chap03.tex V1 - May 18, 2007 12:02 A.M. Page 118

Hammermeister, KaI, The German Aesthetic Tradition (Cambridge: Cambridge University Press, 2002).

Heger, Georg Wilhelm Friedrich, Aesthetics: Lectures on Fine Art, 2 vols., trans. T. M. Knox (Oxford: Clarendon, 1975) [Vorlesungen über die Ästhetik (1823, 1826, 1828-9), in Werke. Auf der Grundlage der Werke von 1832-1845 neu edierte Ausgabe, ed. Eva Moldenhauer and Karl Markus Michel (Frankfurt am Main: Suhrkamp, 1979) (Theorie-Werkausgabe), vols. xiii-xv].

The Encyclopedia Logic: Part 1 of the Encyclopaedia of Philosophical Sciences, trans. T. F. Geraets, W. A. Suchting, and H. S. Harris (Indianapolis: Hackett, 1991) [Die Wissenschaft der Logik (1830), in Werke. Auf der Grundlage der Werke von 1832-1845 neu edierte Ausgabe, ed. Eva Moldenhauer and Karl Markus Michel (Frankfurt am Main: Suhrkamp, 1979) (Theorie-Werkausgabe), vol. vii].

'Foreword to Hinrichs' Religion in its Inner Relation to Science', in Miscellaneous Writings of G. W. F. Hegel, ed. Jon Stewart (Evanston, Ill.: Northwestern University Press, 2002) ['Vorrede zu Hinrichs' Religionsphilosophie' (1822), in Werke. Auf der Grundlage der Werke von 1832-1845 neu edierte Ausgabe, ed. Eva Moldenhauer and Karl Markus Michel (Frankfurt am Main: Suhrkamp, 1979) (Theorie-Werkausgabe), ii. 41-66].

Philosophy of Mind: Being Part Three of the Encyclopaedia of Philosophical Sciences (1830), trans. William Wallace (Oxford: Clarendon Press, 1971) [Die Philosophie des Geistes, in Werke. Auf der Grundlage der Werke von 1832-1845 neu edierte Ausgabe, ed. Eva Moldenhauer and Karl Markus Michel (Frankfurt am Main: Suhrkamp, 1979) (Theorie-Werkausgabe), vol. x].

Heidegger, Martin, Being and Time, trans. John Macquarrie and Edward Robinson (Oxford: Basil Blackwell, 1978) [Sein und Zeit (1927), in Gesamtausgabe (Frankfurt am Main: Klostermann, 1975-), Abt. 1, Bd. 2, ed. Friedrich-Wilhelm von Herrmann (1977)].

'The Origin of the Work of Art', trans. Albert Hofstadter, in Poetry, Language, Thought (New York: Harper \& Row, 1971), 15-87 ['Der Ursprung der Kunstwerkes' (1935-1936), in Gesamtausgabe (Frankfurt am Main: Klostermann, 1975-), Abt. 1, Bd. 5, Holzwege, ed. Friedrich-Wilhelm von Herrmann (1977), 1-74].

Henrich, Dieter, Versuch über Kunst und Leben: Subjektivität-WeltverstehenKunst (München: Hanser, 2001).

Between Kant and Hegel: Lectures on German Idealism, ed. David S. Pacini (Cambridge, Mass.: Harvard University Press, 2003).

Hilmer, Brigitte, 'Kunst als Spiegel der Philosophie', in Andrea Kern \& Ruth Sonderegger (eds.), Falsche Gegensätze: Zeitgenössische Positionen zur philosophischen Ästhetik (Suhrkamp: Frankfurt am Main, 2002).

HöLdERLIN, Friedrich, Hyperion (Die vorletzte Fassung) (1796), in Sämtliche Werke: Große Stuttgarter Ausgabe, iii, ed. Friedrich Beißner (Stuttgart: Kohlhammer, 1957), $235-52$.

'Operations of Poetic Spirit', in Essays and Letters on Theory, trans. and ed. Thomas Pfau (Albany: State University of New York Press, 1988) ['Über die Verfahrungsweise des poëtischen Geistes’ (1800), in Sämtliche Werke: Große 
B. Leiter and M. Rose Chap03.tex V1 - May 18, 2007 12:02 A.M. Page 119

SEBASTIAN GARDNER

119

Stuttgarter Ausgabe, Bd. 4, 1e Hälfte, ed. Friedrich Beißner (Stuttgart: Kohlhammer, 1961), 241-65].

Jacobi, Friedrich Heinrich, Concerning the Doctrine of Spinoza in Letters to Herr Moses Mendelssohn (1785), in The Main Philosophical Writings and the Novel Allwill, trans. George di Giovanni (Montreal and Kingston: McGill-Queen's University Press, 1994), 173-251 [Ueber die Lehre des Spinoza, in Briefen an den Herrn Moses Mendelssohn (Breslau: Gottl. Löwe, 1785)].

David Hume on Faith, or Idealism and Realism, A Dialogue: Preface and also Introduction to the Author's Collected Philosophical Works (1815), in The Main Philosophical Writings and the Novel Allwill, trans. George di Giovanni (Montreal and Kingston: McGill-Queen's University Press, 1994), 537-90 [David Hume über den Glauben, oder Idealismus und Realismus: Ein Gespräch. Vorrede,zugleich Einleitung in des Verfassers sämmtlichte philosophische Schriften, in Werke, ed. Friedrich Roth and Friedrich Köppen, ii (Leipzig: Gerhard Fleischer, 1815; reprod. Darmstadt: Wissenschaftliche Buchgesellschaft, 1976), 3-123].

James, Susan, Passion and Action: The Emotions in Seventeenth-Century Philosophy (Oxford: Oxford University Press, 1997).

Lacoue-Labarthe, Philippe, and Jean-Luc Nancy, The Literary Absolute: The Theory of Literature in German Romanticism, trans. Philip Barnard and Cheryl Lester (Albany, NY: State University of New York Press, 1988).

Megill, Allan, Prophets of Extremity: Nietzsche, Heidegger, Foucault, Derrida (Berkeley: University of California Press, 1985).

Merleau-Ponty, Maurice, 'Cézanne's Doubt', in Sense and Non-Sense, trans. Hubert L. Dreyfus and Patricia Allen Dreyfus (Evanston, Ill.: Northwestern University Press, 1964) ['Le doute de Cézanne', in Sens et non-sens (Paris: Nagel, 1948), 15-49].

'Metaphysics and the Novel', in Sense and Non-Sense, trans. Hubert L. Dreyfus and Patricia Allen Dreyfus (Evanston, Ill.: Northwestern University Press, 1964) ['Le roman et la métaphysique', in Sens et non-sens (Paris: Nagel, 1948), 51-81]

Moore, A. W., Points of View (Oxford: Clarendon, 1997).

Nietzsche, Friedrich, The Birth of Tragedy out of the Spirit of Music and The Case of Wagner, trans. Walter Kaufmann (New York: Vintage Books, 1967) [Die Geburt der Tragödie. Oder: Griechenthum und Pessimismus, in Werke: kritische Gesamtausgabe, ed. Giorgio Colli und Mazzino Montinari, Abt. 3, Bd. 1 (Berlin: de Gruyter, 1972)].

The Gay Science, trans. Walter Kaufmann (New York: Vintage, 1974) [Die fröhliche Wissenschaft, in Werke: kritische Gesamtausgabe, ed. Giorgio Colli und Mazzino Montinari, Abt. 5, Bd. 2 (Berlin: de Gruyter, 1973)].

Novalis, Fichte Studies, ed. Jane Kneller (Cambridge: Cambridge University Press, 2003) [Fichte-Studien, in Schriften, ii, Das philosophische Werke I, ed. Richard Samuel, Hans-Joaquim Mähl, and Gerhard Schulz (Stuttgart: Kohlhammer, 1981)].

Passmore, John, Serious Art: A Study of the Concept in all the Major Arts (London: Duckworth, 1991). 
B. Leiter and M. Rose Chap03.tex V1 - May 18, 2007 12:02 A.M. Page 120

Pippin, Robert, 'What Was Abstract Art? (From Hegel's Point of View)', in The Persistence of Subjectivity: On the Kantian Aftermath (Cambridge: Cambridge University Press, 2005), 279-306.

Railton, Peter, 'Aesthetic Value, Moral Value, and the Ambitions of Naturalism', in Facts, Values, Norms: Essays towards a Morality of Consequence (Cambridge: Cambridge University Press, 2003), 85-130.

Redding, Paul, The Logic of Affect (Ithaca, NY: Cornell University Press, 1999).

Richards, I. A., The Principles of Literary Criticism, 2nd edn. (London: Routledge \& Kegan Paul, 1926).

Rothro, Mark, The Artist's Reality: Philosophies of Art, ed. Christopher Rothko (New Haven, Conn.: Yale University Press, 2004).

SACKs, Mark, Objectivity and Insight (Oxford: Clarendon, 2000).

Sartre, Jean-Paul, Being and Nothingness: An Essay of Phenomenological Ontology (London: Methuen, 1957) [L'être et le néant. Essai d'ontologie phénoménologique (Paris: Gallimard, 1943)].

The Imaginary: A Phenomenological Psychology of the Imagination, trans. Jonathan Webber (London: Routledge, 2004) [L'Imaginaire: psychologie phénoménologique de l'imagination (Paris: Gallimard, 1940)].

Notebooks for an Ethics, trans. David Pellauer (Chicago: University of Chicago Press, 1992) [Cahiers pour une morale (1947-8) (Paris: Gallimard, 1983)].

Sketch for a Theory of the Emotions, trans. Philip Mairet (London: Methuen, 1962) [Esquisse d'une théorie des émotions (Paris: Hermann, 1939)].

What is Literature?, trans. Bernard Frechtman (London: Methuen, 1986) [Qu'est ce que la littérature?, Situations 2 (Paris: Gallimard, 1948)].

Schaeffer, Jean-Marie, Art of the Modern Age: Philosophy of Art from Kant to Heidegger, trans. Steven Rendall (Princeton, NJ: Princeton University Press, 2000) [L'art de l'âge moderne (Paris: Gallimard, 1992)].

Scheler, Max, The Nature of Sympathy, trans. Peter Heath (London: Routledge \& Kegan Paul, 1979) [Wesen und Formen der Sympathie, 6. Auflage, in Gesammelte Werke, vii, ed. Manfred S. Frings (Bern and München: Francke, 1973)].

Schelling, F. W. J., System of Transcendental Idealism (1800), trans. Peter Heath (Charlottesville: University Press of Virginia, 1978) [System des transcendentalen Idealismus, in Schellings Werke. Nach der Originalausgabe in neuer Anordung, ed. Manfred Schröter (München: Beck, 1927-), ii. 327-634].

Schiller, Friedrich, Briefe 1796-98, Schillers Werke: Nationalausgabe, xxix, ed. Norbert Oellers and Fritjhof Stock (Weimar: Böhlaus, 1977).

On the Aesthetic Education of Man: In a Series of Letters, trans. Elizabeth M. Wilkinson and L. A. Willoughby (Oxford: Clarendon, 1982) [Über die äesthetische Erziehung des Menschen in einer Reihe von Briefen (1793-5), in Schillers Werke: Nationalausgabe, xx (Philosophische Schriften, Teil 1), ed. Benno von Wiese and Helmut Koopmann (Weimar: Böhlaus, 1962), 309-412]. 
B. Leiter and M. Rose Chap03.tex V1 - May 18, 2007 12:02 A.M. Page 121

Schlegel, Friedrich, 'Athenaeum Fragments', in Philosophical Fragments, trans. Peter Firchow (Minneapolis: University of Minnesota Press, 1991) ['AthenäumsFragmente', in Kritische Friedrich-Schlegel-Ausgabe, ed. Ernst Behler et al. (Paderborn: Schöningh, 1958 - ), ii ed. Hans Eichner (1967), 165-255].

'Ideas', in Philosophical Fragments, trans. Peter Firchow (Minneapolis: University of Minnesota Press, 1991) ['Ideen', in Kritische Friedrich-Schlegel-Ausgabe, ed. Ernst Behler et al. (Paderborn: Schöningh, 1958-), ii, ed. Hans Eichner (1967), 256-72].

Schleiermacher, Friedrich Daniel Ernst, The Christian Faith, ed. H. R. Mackintosh and J. S. Stewart (Continuum/T. \& T. Clark: London, 1999) [Der christliche Glaube nach den Grundsätzen der evangelischen Kirche im Zusammenhange dargestellt, 2nd edn. (1830), in Kritische Gesamtausgabe, Abt. I, Bd. 13, Teilbde. 1-2, ed. Rolf Schäfer (Berlin: de Gruyter, 2003)].

On Religion: Speeches to its Cultural Despisers, trans. and ed. Richard Crouter (Cambridge: Cambridge University Press, 1996) [Über die Religion: Reden an die Gebildeten unter ihren Verächtern (1799), in Kritische Gesamtausgabe, Abt. I, Bd. 2, ed. Günter Meckenstock (Berlin: de Gruyter, 1984)].

Schopenhauer, Arthur, The World as Will and Representation, i, trans. E. F. J. Payne (New York: Dover, 1969) [Die Welt als Wille und Vorstellung (1st edn. 1819, 2nd edn. 1844), vol. i, in Sämtliche Werke. Neu bearbeitet, ed. Arthur Hübscher, vol. ii (Wiesbaden: Brockhaus, 1949).]

Steiner, George, Real Presences: Is There Anything in What We Say? (London: Faber and Faber, 1989).

Stolnitz, Jerome, 'On the Cognitive Triviality of Art', British Journal of Aesthetics 32 (1992), 191-200.

Sullivan, J. W. N., Beethoven: His Spiritual Development (London: Jonathan Cape, 1927).

Young, James O., Art and Knowledge (London: Routledge, 2001).

Zuidervaart, Lambert, Artistic Truth: Aesthetics, Discourse, and Imaginative Disclosure (Cambridge: Cambridge University Press, 2004). 